\title{
Entrepreneurship in China and India
}

\author{
Sangaralingam Ramesh ${ }^{1}$
}

\begin{abstract}
Research to date has not explored the role of entrepreneurship has a key driver of China's economic growth; and how the nature of entrepreneurship may differ between India and China in this context. This difference will have implications on the extent of entrepreneurship as a driver of Indian economic growth. The aim of this paper is to fill this research gap. Furthermore, one of the central premises of this paper is that the economic reforms in China have provided an incentive for the Chinese to embrace their uniquely cultural entrepreneurial skills. However, this has not happened in isolation because the reforms have targeted all sectors of the economy, the most important of these reforms for entrepreneurial facilitation has been associated with infrastructure, education, property rights, ownership restructuring and foreign direct investment. In this case, changes in infrastructure, knowledge creation and knowledge spillovers have led indirectly to China's economic growth. In the case of knowledge spillovers this has happened because knowledge spillovers have been facilitated by entrepreneurship. And this has been characterised by the dynamic nature of institutional change. Nevertheless, in India at state level there is variation in the level of economic, institutional and infrastructural development. Moreover, there is a tendency for firms in India to remain small. This may be due to the country's rigid labour laws. The findings of this paper indicate that entrepreneurship is stronger in China than in India from a cultural and a historical perspective. Entrepreneurship has been stimulated in China by the incrementally evolving economic reforms which resulted in the dynamic nature of institution formation. However, entrepreneurship in India remains constrained by institutional factors; and institutional rigidity. Due to this the social entrepreneurship is more prevalent in India than in China.
\end{abstract}

Keywords China, India, Entrepreneurship, Innovation, Economic Growth

\section{Introduction}

The aim of this paper is to show that entrepreneurship in China has played an important role in its economic growth. The objective of this paper will be to show how the nature of entrepreneurship differs between China and India in this context. The theoretical framework on which this paper will depend will be the Solow model which predicts that short term economic growth is dependent on increases in investment in fixed capital, with long term growth being based on innovation. Within this framework there is no role for entrepreneurship as the basis for knowledge spillovers and economic growth. Entrepreneurship has, therefore, considerable more importance in reality to economic growth than given credit by models such as the Solow Model. The methodology to resolve the aims and the objectives will be a case study of entrepreneurship in India and China based on the contextual use of a literature survey and an analysis of data reflecting the emergence of private enterprise in China and India after the economic reforms of 1978 and 1991 respectively. The results will show that entrepreneurship emerged much more strongly in China than it did in India. The reason for this is that institutional development is more flexible in China than it is in India.

Entrepreneurship in China has been facilitated by the incremental economic reforms which started in 1978. These reforms essentially focused on transforming the economic role of infrastructure; and facilitating knowledge creation and knowledge spillover mechanisms in the transition from that of a centrally planned

\footnotetext{
${ }^{1}$ S. Ramesh

Department for Continuing Education, University of Oxford, Rewley House, 1 Wellington Square,

Oxford, Oxfordshire OX1 2JA, UK

E-mail: Sangaralingham.ramesh@conted.ox.ac.uk
} 
economy to a hybrid free market economy. This process was closely associated with the re-emergence of entrepreneurship. However, in contrast to China Indian entrepreneurship has played a lesser role in the country's economic growth. Often, instead fulfilling a social function. The objective of this paper is to show that the contextual roles of entrepreneurship in China's economic growth and in India's economic development have arisen due to differences in the formation of institutions between these two countries. In the case of China, the years of chaos and civil war gave the country a 'clean slate' upon which to experiment, with different economic strategies and policies, after 1949. First the Great Leap Forward, then the Cultural Revolution; and then the free market incremental economic reforms of 1978. These reforms facilitated the development of adaptable and flexible institutions. On the other hand, in the case of India, the history of colonial British rule gave way to institutional rigidity. The implication of this is that in China, entrepreneurship has flourished while in India it is lagging. The methodology used to establish the nature of institutional development as well as the nature of entrepreneurship in China and India will be a case study based on an analysis of the literature as well as relevant economic data.

Infrastructure investment in small densely populated geographical areas favours the development of increased levels of new business density in these areas. The higher the business density, the bigger the contribution to a country's economic growth. For example, economic growth and prosperity tends to be higher in city states such as Singapore and Hong Kong compared to countries with a comparably larger surface area and smaller business densities. According to the World Bank (2016), new business density in India was 0.12 (smaller coverage of a populated geographical area by business enterprises) while in Hong Kong SAR, China it was 31.3 (larger coverage of a populated geographical area by business enterprises). The new business density is measured as the ratio of the number of newly registered corporations per 1000 working age people between the ages of 15 and 64, (World Bank, 2016). However, there is no measure, perhaps due to the lack of availability of data, for the measure of new business density in mainland China. In this case, the new business density for Hong Kong SAR can act as a proxy for the measure in mainland China. Hong Kong SAR and mainland China are ideal proxies, because both have a similar culture and the mainland has benefited hugely from investment, in small geographical areas by firms, from Hong Kong SAR. Furthermore, according to Zoltan et al (2016), in terms of the level of entrepreneurship, China is at $60^{\text {th }}$ position in the world with an entrepreneurial measure of 34.9 ; with India at position $98^{\text {th }}$ in the world with an entrepreneurial measure of 24.9. Measuring the level of entrepreneurship at a country level allows for an appreciation of the extent of free market forces within that country. Furthermore, determining and understanding the factors which facilitate entrepreneurial activity will allow an insight into why some countries have higher levels of economic growth than do other countries, (Hafer et al., 2015). Entrepreneurship can be measured by using both the Global Entrepreneurship and Development Index (GEDI), developed by Acs and Szerb (2010), and by the Global Entrepreneurship Monitor (GEM). Another measure of entrepreneurship, is an output based one which, is based on the number of private limited liability companies which are entering the market. This is the World Bank's Entrepreneurship Survey 2014. One disadvantage of using this measure is that it may not be a universally comparable measure of entrepreneurship because different countries have different regulations regarding how firms are set up. Furthermore, the nature and the development of entrepreneurship varies from country to country due to cultural, historical, linguistic, religious, institutional, resource access and infrastructural differences, Bruton et al (2008). The implication is that research into entrepreneurship should not be generalised but should be dependent on country by country basis. Secondly, the measure does not account for the informal entry of firms into the market. So, it may underestimate the level of entrepreneurial activity in the economy, (Hafer et al., 2015). The level of cognitive skill can be measured using the IQ series published by Lynn and Meisenberg (2010).

People with more ability in terms of motivating and managing others, strong time management and organisational skills, tenacity, good interpersonal skills and the ability to take risks seem to have higher incomes as entrepreneurs than the wages they would be able to earn as workers. Thus, general cognitive ability is more important and it has a bigger impact on entrepreneurs than on workers, (Hartog et al., 2010). This is because people with a high level of cognitive skills will tend to be more creative; and be better able to start and manage a firm in order to innovate than those with a lower level of cognitive skills who would more likely be workers, (Van Praag et al., 2013). Therefore, the education of entrepreneurs rather than that of workers has a bigger impact on a country's economic growth and economic development, (Gennaioli et al., 2013). Furthermore, according to research, opportunistic entrepreneurs tend to be more educated then are necessity based entrepreneurs, (Bergmann et al., 2007). Furthermore, necessity based entrepreneurs are less likely to be educated in the sector in which they start the business, (Block et al., 2009). Perhaps education may better improve the cognitive skills of the entrepreneur class than the cognitive skills of the worker class. A higher level of cognitive skills will reduce income inequality, (Meisenberg, 2012). Income inequality is measured using the Gini coefficient. The Gini Coefficient has a value between 0 and 1. If the Gini Coefficient is close to 0 then it means that there is perfect income equality and if it is close to 1 then it means that there is complete income inequality, Arnold (2008). In China income inequality tends to be lower for urban residents then it is for rural ones, (Zhou et al., 2012). This difference could be explained by the knowledge that urban areas tend to represent 
an environment which is conducive to innovative entrepreneurship than are rural areas, (Baporikar, 2015). This could be because urban areas represent a bigger market, economic density as well as a more educated workforce than can be found in rural areas of China. Therefore, urban areas tend to have larger incomes than would rural ones.

\section{Institutional Differences between India and China}

The Solow model emphasises the role of capital accumulation in facilitating the short term economic growth of an economy. But the model emphasises the role of technological progress in facilitating the long term economic growth of an economy. However, while some countries, for example Taiwan, South Korea and Japan, have converged with the GDP per capita of the United States, the world's leading economy since 1945, other countries such as the Sub-Saharan African countries have seen a divergence. The convergence-divergence paradox can be explained by the absence of institutions leading to political and economic instability causing economic growth to take off, stall and perhaps even drop. In this context, the role of institutions in the economic development of India and China needs to be evaluated.

An institution can be regarded as a human construct which facilitates transactions between the buyers and sellers of a good; and so ultimately it is the root of how resources such as labour and capital can be allocated in the process of production by firms, in order to achieve the maximum level of profits. Economic development and institutions have a causative relationship, (Lin et al., 1995). The implication of this is that the presence of efficient and stable institutions may facilitate economic development which spurs institutional evolution. If a country lacks effective institutions, due to either excessive government control and/or from a historical context, then this may suggest that it will suffer from poor economic development. However, market oriented reforms will help institutions to form and evolve over time. But the consistency of the quality of institutions across the regions of a country will depend on the extent of central government involvement in the evolution of the institutions, (Nundy, 2016). Market oriented reforms can take the 'big bang' approach where economic liberalisation occurs in all sectors of the economy at the same time or it can take an incremental approach with economic liberalisation taking effect in one sector at a time, over time. India took, or was forced to undertake the 'big bang' approach by the IMF, while China's economic reforms were gradual and incremental. However, the dynamic of institutional change in China following the Tiananmen Square crisis could not be explained by existing structuralist theories of institutional change such as economic institutionalism, socio-political institutionalism or historical institutionalism, (Gilley, 2008). In this case, the latter suggests that all institutional change in China after 1989 has been contained and brought about by the legitimacy of the state. Such legitimate institutional change has facilitated the primacy of the party, corporate tax reforms, the fiscal relationship between the central government and provincial governments, elections in self-managing villages, increased state control and the founding of the National Corruption Prevention Bureau. ${ }^{2}$

India gained independence from Britain in 1947 and China was declared the People's Republic of China in October 1949. At that time, the main features of each of these countries' economies encompassed both a feudal mode of agricultural production as well as mass rural poverty, (Saith, 2008). Moreover, the latter suggests that at a cultural level both countries shared gender bias, child marriage and female infanticide. However, the main distinguishing feature between the two countries was that while China has an almost homogenous racial and linguistic profile, this is not true of India which is home to many languages and many races, despite Hinduism and Hindi being the predominant religion and culture. The homogeneity of race and language in China allowed for easier control and direction of the population by the state towards its own ends. Indeed, in China the homogeneity of race and culture allowed for the flexibility in the transformation of institutions over a very short space of time, whereas the complexity of the demography of Indian society made institutional development difficult. ${ }^{3}$ While both countries were predominantly agrarian with significant rural poverty, there was a lack of institutional drivers to translate any agricultural surplus into industrial production and economic growth. However, there was a significant difference between the agrarian systems of both India and China after independence and the end of the civil war respectively. This difference related to the power of the land-owning class. In China, the land-owning class was swept away by the communist victory of 1949, while in India the land-owning class not only survived in a newly independent India, but became embedded in the Congress Party, (Saith, 2008). The latter suggests that this cohesion of land ownership and political power acted to prevent land reform from which tens of millions of Indian tenant farmers would have benefited. Moreover, China was not as much affected by British colonialism as was India. The consequences of the British Raj for India were that once independent it inherited an overwhelmingly middle class which was highly educated in English. ${ }^{4}$ This was a comparative advantage to the Indian economy, endowed by colonial rule, developed further by Nehru's

\footnotetext{
${ }^{2}$ Gilley, B. (2008), Legitimacy and Institutional Change: The Case of China, Comparative Political Studies, Vol. 41, No.3, pp.259-284.

${ }^{3}$ Saith, A. (2008), China and India: The Institutional Roots of Differential Performance, Development and Change, 39 (5), pp. 723-757.

${ }^{4}$ Ibid.
} 
objective of strengthening the Indian economy on the basis of promoting scientific education. This led to an abundance in low paid highly skilled labour in India which would benefit in the era of globalisation due to the outsourcing to India of software production and other services to Indian firms. In contrast, in China, land collectivisation over time led to skills development which would be of advantage in the development of China's export led manufacturing sector following the economic reforms of 1978. The roots of India's postindependence emphasis on education and China's post-revolutionary focus on the collectivisation of agriculture lay in its post-independence/revolutionary system of governance. ${ }^{5}$ However, both countries economic development plans also focused on the development of heavy industry. Nevertheless, in China, political power became concentrated in the hands of the poor, the workers and the peasants, through the Chinese Communist Party. On the other hand, in India political power became concentrated in the hands of the English educated upper castes, through the Congress Party. Some point to this reason as the cause of the divergence in the economic prosperity of the two countries. China started its economic reforms in 1978 while India did not start its economic reforms full throttle until the early 1990's. The roots of differential economic performance between the two countries lies in the differences in the concentration of political power after independence in India's case and the conclusion of the civil war in China's case. In India, the concentration of political power in the English educated elite upper castes resulted in agricultural surpluses being retained by landowners. However, in China's case the concentration of political power led to state accumulation of agricultural surpluses benefitting peasantry by supporting human development through industrialisation. This was simply due to the strength of the linkages between rural agricultural collectives and rural industry. ${ }^{6}$ But in the case of India the strength of the linkage between rural agriculture and rural industry was weak because agricultural surplus was expropriated by land owners. As a result, tenant farmers and lower castes did not benefit from skills development through rural industrialisation as did the peasantry in China. This benefitted the Chinese economy to take advantage of its abundance of cheap labour, part of which had benefitted from rural industrialisation through skills acquisition, in the reform years after 1978 to achieve sustained economic growth through the export of light manufactured goods. However, although the supply of labour in China and India seem to be limitless, as a source of advantage it has limitations, (Altenburg et al., 2007). In the case of China, fewer people are being born and the current population is getting older. But in the case of India while a larger part of the population is younger, there is a question as to whether the educational system can supply workers who are employable. ${ }^{7}$

In China, as in India there is both a formal and an informal financial sector. The formal sector consists of the four state owned banks; and the informal sector consists of pawnbrokers and money lenders as well as institutions banned by the People's Republic of China such as private money houses and informal banks, (Ayyagari et al., 2010). The latter also suggests that the corporate bond market cannot function properly due to the lack of credit rating agencies being unable to price debt accurately, government regulation and a negligible pool of institutional investors. Furthermore, ill-defined private property rights, a lack of corporate transparency and political corruption ensures that the stock markets in Shanghai and Shenzhen do not function as effectively as they should, (Durnev et al., 2004). In order to alleviate constraints on the availability of finance to poor rural households, which could prevent them from becoming entrepreneurs, central governments in both India and China started microfinance programs such as the Poverty Alleviation (PA) program in which poor rural households would be targeted for subsidised poverty loans. However, local politicians in India diverted PA funds to local elites as did provincial officials in China, (Yaron et al., 1997). As a result, repayments were low; and the repayment rate was even lower in China because PA loans were considered to be 'soft loans'.

Furthermore, in India and China microfinance initiatives tend to be less popular as sources of finance for poor households compared to the informal sector, (Tsai, 2004). The latter cites four reasons as to why this may be the case. Firstly, formal credit is limited in supply. Secondly, state institutions are too weak to enforce policy. Thirdly, local markets are economically and politically fragmented. And finally, microfinance programs are themselves subject to institutional deficiencies. However, while the informal financial sector (money lenders/shadow banking) in China is a preferential source of loans to poor, rural households, individuals and small firms, it has been found that large firms tend to borrow from the formal sector through the state-owned banks; and this correlates with these firm's performance, (Ayyagari et al., 2010).

The rapid growth of the Chinese economy compared to the Indian economy lies with the nature of the institutional framework. ${ }^{8}$ In China, the civil war and the revolution changed the dynamic of the institutional framework from a feudal orientation to a people's direct action orientation. On the other hand, in India, independence merely transferred and cemented the political power of the upper caste English educated elite. As a result, China's institutional framework was more flexible and malleable than was India's institutional framework. This flexibility led to China's economic reforms changing and adapting institutions relative to state

\footnotetext{
${ }^{5}$ Ibid.

${ }^{6}$ Ibid.

${ }^{7}$ Altenburg, T., Schmitz, H., and Stamm, A. (2007), Breakthrough? China's and India's Transition from Production to Innovation, World Development, Vol.36, No.2, pp.325 - 344.

${ }^{8}$ Ibid.
} 
ownership and free market forces. But state led institutions led to a lot of time consuming transactions, (Lai et al., 2016). Furthermore, the extent to which different cities and regions in China are able to adapt from the after effects of global economic crises, such as the banking crisis of 2008, depends on the capability and quality of the local leadership, capacity for innovative policy making and the level of power to implement policy, (Shen $e t$ al., 2016). In the case of India, economic reforms did not impact on institutions effectively due to institutional rigidities. Thus, whereas the role of agriculture in China led to positive externalities on rural skill development and rural industry, in India changes in the agricultural sector led to the displacement of agricultural workers and the loss of incomes by workers and tenant farmers. ${ }^{9}$ The agricultural sector in India and China has also been affected by institutional reforms with regards to agricultural R\&D policy, although the focus of these reforms has differed between India and China, (Pal, 2008). According to the latter, the reforms in China has led to the increased commercialisation of the results of publicly funded research leading to the increased generation of financial resources. However, in India the reforms have facilitated the emergence of private sector research over public sector research. Nevertheless, in the case of both countries the government could give support to small farmers in the use of advanced technology, (Pal, 2008). Furthermore, the latter suggests that both countries would benefit by co-operating in increasing the productivity of low quality land as well as in agricultural biotechnology. In the context of the advancement of software engineering, China should enhance its intellectual property laws; and India should improve its telecommunications and transport infrastructure, (Zhao et al., 2008). Competition from other countries and insufficient R\&D expenditure may also hold back the IT industry in both India and China, (Yip et al., 2009). In the wider context of the internalisation of R\&D, MNC's investing in China and India would also benefit from these countries increasing spending on R\&D as well as on science and technology education, (Asakawa et al., 2008). National institutional development would also benefit from consistent central government financial support, (Moore, 1984). In the case of Chinese emerging market enterprises (EME's) doing business with other countries, it has been found that the institutional development of host countries impacts positively on the innovative performance of the EME's, (Wu et al., 2016). However, according to the latter, this depends on the absorptive capacity of the EME as well as the extent of the EME's investments in other countries. In contrast, state owned EME's tend to benefit more when entering countries with less institutional development, (Wu et al., 2016).

Both India and China are transition economies, the former moving away from central planning in the 1980's and more fully after 1991, while the latter began the transition in 1978. Institutions, such as clearly defined private property rights, which are not prevalent in India and China are much more in evidence in other mixed market economies, such as the US, the EU and Japan where there is a mixture of government intervention and free market forces at play in the allocation of resources. In order to support free market forces and the efficacy with which they function, institutions are important. These institutions encompass governance, property rights, the tax regime, the financial system, labour market and training, education and research and cultural factors. In a general context, institutions can be thought of as the laws, regulations and cultural factors which determine the structure of human political, economic and cultural interactions, (North, 1990). The nature of governance impacts on the enactment of laws and regulations and thus on private property rights. For example, in the US the system of governance is a democracy, valuing political choice and individual freedom. On the other hand, in China the system of governance is based on a technocracy where political choice and individual freedom are not as important as economic choice. China's unitary form of governance allows for effective policy formulation and implementation compared to the India's pluralistic form of governance in which effective policy formulation and implementation is difficult, (Araral et al., 2016). This gives rise to differences towards the treatment of property rights. The nature of property rights has an impact on the extent of entrepreneurial activity. In the US, private property rights are enshrined in the law whereas in China they are not as fully integrated into the legal system although private property rights have been formally endorsed by the CCP. Thus, in the US there may be individual property rights but in the case of China it becomes more of a question of property privilege ${ }^{10}$ because of the pre-eminence of state ownership over that of individual ownership. Furthermore, in the US there is a separation of the judiciary and individual property rights. But in China this separation of powers is not possible because of state ownership. Moreover, such a separation of powers may cause chaos in a society which espouses to the idea of a Confucian 'harmony', (Puffer et al., 2010). The latter refers to a balance between 'body, mind and the environment' as well as between 'heaven, earth and humanity', (Xiaoyi, 2015). Nevertheless, because of rent seeking activities by local authorities, grabbing land from farmers and from villagers for development, there may be a need to protect property rights on a legal basis. However, the development of a rights based legal system has been constrained by traditional Confucian values which espouses family values and the benevolence of the ruler rather than on the management of societal

\footnotetext{
9 Saith, A. (2008), China and India: The Institutional Roots of Differential Performance, Development and Change, 39 (5), pp. 723-757.

${ }^{10}$ Puffer et al. (2010), Entrepreneurship in Russia and China: The Impact of Formal Institutional Voids, Entrepreneurship Theory and Practice, May 2010.
} 
relationships through a codified legal system. Family networks reduce and mitigate risks which may not be possible with a formal codified system of laws and regulations.

As China's economy evolves over time the growth in the size of firms as meant that some firms prefer to have a listing on a stock exchange outside China, thereby putting their faith in western institutions while maintaining a foot inside China. The result may be that while formal institutions associated with legal protection of property rights may not arise in China, there has been a process of institutional off-shoring by Chinese firms. ${ }^{11}$ However, in the case of 16 transition economies in Central and Eastern Europe it has been found that domestic institutional changes brings benefits to domestic firms challenging the long held traditional view that such domestic institutional changes benefit multi-national corporations, (Kafouros et al., 2016). Moreover, it has been found that there is no evidence to suggest either beneficial or non-beneficial effects of FDI from developing or developed countries to developing countries to their institutional development, (Demir, 2016).

Puffer et al (2010) develop an analysis of the nature of entrepreneurship in China based on a combination of the fragility of private property rights and a reliance on informal networks and Guanxi. This business practice, to diffuse bureaucracy and facilitate transactions and services, may arise from existing relationships or on the basis of relationships which evolve from existing relationships. In this case, the practice and process of Guanxi should not be seen as being static but dynamic in nature. ${ }^{12}$ In transition economies, such as India and China, the fragility of the nature of private property rights gives way to a reliance on informal institutions such as a network of family and/or local business practice such as Guanxi in China. ${ }^{13}$ Therefore, in China cultural values contributes significantly towards entrepreneurship at a micro level then it does in India. It has been recognised that cultural values, the extent of the development of the educational system and even religion shapes behavioural nature towards entrepreneurship, (Bruton et al., 2008). Entrepreneurial activity can be constrained by cultural and institutional factors, (North, 1990). However, entrepreneurial activity can also be facilitated by institutional changes, (Bruton et al., 2003).

In China, the lack of a formal institutional void has been avoided because of the government's management of the transition from a planned economy to a mixed market economy. ${ }^{14}$ However, where there is a lack of formal institutions or formal institutions are ineffective, informal institutions in China and some of the better states in India, act as a substitute improving the efficacy of corporate governance leading to an improvement in the environment for domestic and foreign investment. ${ }^{15}$ In China's case, the centrally planned economy has not been dismantled but allowed to run in parallel with the emerging market economy. Moreover, China's economic transition has been based on incremental change in the formation and in the development of institutions. However, India followed a big bang approach to institutional change rather than following an incremental approach. Therefore, in the case of China the centrally planned state system supported the development of private sector entrepreneurial activity whereas in India it did not. Furthermore, the institutional reforms which China implemented in order to facilitate and encourage entrepreneurship have been a success, (Gupta et al., 2014). So much so that private enterprises have been playing a major role in acting as the dynamo of China's economic growth, (Guo et al., 2010). However, in the case of India, Indian policymakers could gain much wisdom from studying how China was successfully able to instigate appropriate institutional reform which has allowed entrepreneurial activity to flourish. Nevertheless, India does have programs in place to allow entrepreneurs to update skills, the regulatory regime, value system and caste immobility constrain entrepreneurial activity at the micro level in India ${ }^{16}$. In China, the economic reform process since 1978 gave rise to the private sector and the blossoming of entrepreneurial activity. This can be evidenced by the increase in total factor productivity (TFP) with regards to Chinese manufacturing compared to Indian manufacturing. The Chinese institutional changes which led to this occurred in the late 1990's, starting with the formal endorsement of private property rights, leading to an increase in entrepreneurial activity, as well as the retrenchment of unproductive labour, increasing productivity. These two institutional changes account for $30 \%$ of the growth of TFP in Chinese manufacturing compared to Indian manufacturing in the period 1998 to $2003^{17}$.

The 1978 economic reforms were enhanced by the low level entrepreneurial activity of near destitute peasantry. ${ }^{18}$ This type of entrepreneurship is necessity based entrepreneurship. Since the start of the economic

${ }^{11}$ Ibid.

12 Ibid.

${ }^{13}$ Puffer et al. (2010), Entrepreneurship in Russia and China: The Impact of Formal Institutional Voids, Entrepreneurship Theory and Practice, May 2010.

${ }^{14}$ Ibid.

${ }^{15}$ Estrin, S., and Prevezer, M. (2011), The role of informal institutions in corporate governance: Brazil, Russia, India and China explained, Asia Pac J. Manag, 28, pp.41-67.

${ }^{16}$ Gupta, V., Guo, C., Canever, M., Yim, H., Sraw, G., and Liu, M. (2014), Institutional environment for entrepreneurship in rapidly emerging economies: the case of Brazil, China, India and Korea, Int Entrep Manag J, 10, pp.367-384.

${ }^{17}$ Mandey, M., and Dong, X. (2009), Manufacturing Productivity in China and India: The role of institutional changes, China Economic Review, 20, pp.754-766

18 Puffer et al. (2010), Entrepreneurship in Russia and China: The Impact of Formal Institutional 
reforms of 1978, the development of entrepreneurship in China has become increasingly officially espoused over time. However, the development of entrepreneurial activity in China has been uneven and has faced challenges such as the personal purification campaigns by the conservatives in the CCP in the 1980's; as well as in the aftermath of the Tiananmen Square crisis in 1989. ${ }^{19}$ Nevertheless, the flames of economic reform were reignited following Deng Xiaoping's southern China tour which also included a visit to Shenzhen. As the reforms progressed in the 1990's the entrepreneurial class became stronger and more widespread in Chinese society, such that every family represented an entrepreneurial unit. The widespread nature of entrepreneurship in China and the growing financial strength of the financial class took the attention of the Chinese Communist Party. The party's by-laws were changed in 2002, so that entrepreneurs could become party members. ${ }^{20}$ Once party members, these entrepreneurs were easily able to tap financial resources and transitioned from market entrepreneurs to bureaucratic entrepreneurs. ${ }^{21}$

In China, there has also been institutional changes in the field of environmental management, (Lo et al., 2006). Firstly, Environmental Protection Bureau's (EPB's) are not allowed to keep any part of the pollutions fees and fines which they collect. Secondly, EPB core functions have become privatised with a significant reduction in the involvement of state owned enterprises and more environmental protection work being taken up by private sector firms. These changes make environmental protection work more effective and removes the risk of political rent seeking activities by EPB's. ${ }^{22}$ China has also shown its superiority over India with regards to institution formation in the context of a Designated National Authority (DNA) for the approval of a Clean Development Mechanism (CDM). ${ }^{23}$ The CDM allows countries to receive credits towards meeting their obligatory emission targets under the Kyoto Protocol by investing in emission reduction projects in other countries. China's DNA identifies and focuses on investing in priority sectors of a country's economy, but India's DNA's approach has led to failed projects and not all opportunities being grasped. ${ }^{24}$ In the area of water management and conservation, China is also institutionally better off because it has one institution responsible for water management/pricing, the Yellow River Conservancy Commission, whereas in India state governments manage water resources within their states, giving rise to conflicts between states which could lead to inefficiency. ${ }^{25}$ The existence of the YRCC has not led to conflicts between provinces in the Yellow River Basin in China. Furthermore, local government in China manages local water utilities and is also able to increase water tariffs without central government approval. This is not the case in India. China also had more financial resources to invest in its water infrastructure than did India. ${ }^{26}$

\section{Entrepreneurship and Economic Growth}

Entrepreneurship encompasses a creative phenomenon in which an individual or a group of individuals are able to identify a niche in the market for a good or service and exploit this niche by allocating resources such as labour, land and capital in order to make a profit. Entrepreneurs seeking profit are able to allocate resources such as labour and capital in the context of a firm; and by doing so entrepreneurs facilitate the division of labour and economic growth, (Smith, 1776). Furthermore, an understanding of the role of the entrepreneur will allow for a successful analysis of how labour, capital and technology are able to interact in order to facilitate economic growth, (Holcombe, 1998). According to Solow $(1956,1957)$ economic growth occurred because of increases in investment in capital which allowed workers to become more productive over time. However, over time any additional investment was 'swallowed' up by having to replace existing capital so 'new' investment resulted in diminishing increases in worker productivity. Knowledge was assumed to be freely accessible to all firms and in the econometric estimation of the production function, knowledge was assumed to be represented by the residual, (Solow, 1957). And economic growth occurred in the long run through permeable technological change. Therefore, economic growth and economic development in the long run are facilitated by entrepreneurship, (Carree and Thunk, 2003). However, two distinct types of entrepreneurship have been

Voids, Entrepreneurship Theory and Practice, May 2010.

${ }^{19}$ Ibid.

${ }^{20}$ Pomfret, J. (2001). New deal For China's capitalists: Businessmen join party but run their own show. The Washington Post, $3^{\text {rd }}$ July 2001.

${ }^{21}$ Puffer et al. (2010), Entrepreneurship in Russia and China: The Impact of Formal Institutional Voids, Entrepreneurship Theory and Practice, May 2010.

${ }^{22}$ Lo, C., and Tang, S. (2006), Institutional reform, economic changes, and local environmental management in China: the case of Guangdong Province, Environmental Politics, 15:62, pp.190-210.

${ }^{23}$ Ganapati, S., and Liu, L. (2008), The Clean Development Mechanism in China and India: A Comparative Institutional Analysis, Public Administration and Development, 28, pp.351-362.

${ }^{24}$ Ibid.

${ }^{25}$ Araral, E., and Wu, X. (2016), Comparing water resource management in India and China: policy design, institutional structure and governance, Water Policy 18, pp.1-13.

${ }^{26}$ Ibid. 
identified, (Koster et al., 2008). These include the opportunistic entrepreneur and the necessity entrepreneur. Opportunistic entrepreneurs focus their firm's activities on unexplored niche markets and/or innovative products. However, necessity based entrepreneurs undertake entrepreneurial activities because they do not have any other way to generate sustainable income. The Schumpeterian view on economic growth is that it is facilitated by opportunistic firms establishing new processes and new product lines; and by so doing challenge the products and processes of incumbent firms. The latter have to innovate in order to survive; and if not the market is reorganised by a process of 'creative destruction'. According to Koster et al. (2008) the process of 'creative destruction' facilitates regional productivity and regional competitiveness leading to regional economic development. 'Creative destruction' is also more likely to occur in developed countries with more mature markets than it is in developing countries in which necessity based entrepreneurship is more likely to be dominant, (Koster et al., 2008). According to the latter this is due to the lack of employment opportunities, in developing countries, as well as other opportunities to develop a sustainable income.

The work of Lucas (1993) and Romer (1986) ensured that knowledge became associated with externalities and spillovers. Knowledge creation in one firm may 'spill over' into the market due to the commercialisation of a product. Once knowledge spillovers were included in economic growth models, the focus of public policy shifted from economic growth on the basis of investment in capital and the subsequent increase in labour productivity to knowledge, (Audretsch, 2007). However, the latter suggests that knowledge spillovers were constrained by 'knowledge filters' which prevented the commercialisation of knowledge by a third party. Thus, public policy initiatives to invest in knowledge promotion projects did not generate the desired level of economic growth. Nevertheless, entrepreneurship bypasses the knowledge filter and thus represents the 'missing link between investments in new knowledge and economic growth', (Audretsch, 2007). But, the allocation of entrepreneurial capital amongst different types of economic activity depends on government laws, regulations and public and economic policies, (Baumol, 1990). For example, housing reform in urban China which allowed state employees to buy the state-owned housing they were renting at subsidised prices facilitated an increase in self-employment, (Wang, 2012). The latter suggests that the positive relationship between urban housing reform and self-employment resulted from reduced labour mobility costs and a reduction in household capital constraints due to the wealth effect arising from property ownership.

The Chinese economy like the Indian economy is an economy in transition. The economic reforms began in China in 1978. However, in India the economic reforms progressed in spasms with initial reforms in the 1980 's embracing the private sector followed by necessary reforms in the early 1990's due to India's balance of payments crisis. The reforms in both countries have ensured that entrepreneurship has occurred in the background of chaotic, unstable institutional transformation, (Yang et al., 2008). The evolution of entrepreneurial activity in India and in China have been different to that in advanced economies, (Ahlstrom and Bruton, 2002). In China to a greater extent than in India, entrepreneurship 'took root' in response to the economic reforms which introduced market forces into the Chinese economy. In a country, whose economy had been based on central planning for twenty-nine years, the removal of the pillars of central planning from the various sectors of the economy left a void for goods and services which could only be filled by the emergence and the activities of the entrepreneur, (Tan, 2005). Furthermore, government initiatives to introduce new programs (the Spark Program), institutions such as Science and Technology Research Parks as well as the deregulation of the economy, (Yang et al., 2008), have facilitated economic growth due to the application of supply side policies. Thus, these initiatives have facilitated more firms to be set up and to enter the market with a resultant increase in aggregate supply and national output. The rise of the middle class in China has also resulted in an increase in consumption which has again given rise to opportunities, to correct market distortions and market deficiencies, which could be grasped by entrepreneurial activity, (Tsang, 1994). However, the market transition of the Chinese economy is not yet complete because the Chinese economy remains a hybrid market-planned economy. In this case, entrepreneurship may still face constraints not present in more advanced economies, (Zapalska et al., 2001). In the initial stages of economic reform the economy was dominated by the state. Non-state enterprises had a subsidiary role of supporting state enterprises, (Fan, 1996). This would put them at the mercy of local government policies, (Wing et al., 2000).

The emergence of Chinese entrepreneurship, in the aftermath of the economic reforms of 1978, is clearly different from the state of entrepreneurship in advanced economies due to the demanding external environment faced by Chinese entrepreneurs. This demanding external environment included fragmented markets resulting in poorly developed market forces as well as a lack of clearly defined property rights, (Ahlstrom et al., 2002). However, the harsh external environment to entrepreneurship in China is mitigated by guanxi. In China guanxi plays a significant role in doing business. Guanxi refers to the use of contacts and networks in order to further and progress business interests. According to Pan et al (2010) the 'result of guanxi is a network of social obligation'. In economic terms, guanxi may represent the most efficient means by which labour and capital can be allocated for a profitable outcome. This is because it may reduce the transactions and search costs of doing business. 


\section{Case Study: Entrepreneurship in China and India}

\section{Entrepreneurship in China}

The Communist victory in 1949 led to the private sector being eliminated in China by 1956. Under the Communists China became a centrally planned economy with the government deciding on what was to be produced and how much was to be produced. In effect the government decided on the allocation of specific factors of production in order to produce specific outputs. As a result, the government would maintain a monopoly on the production and the distribution of goods and services. While the formal private sector had been eliminated, an informal and efficient rent seeking private sector emerged by filling gaps which the formal economy could not fulfil, (Liao et al., 2001). The inability of the Chinese economy to offer a decent standard of living to the people led to the 1978 economic reforms which started with the decollectivisation of agriculture. However, it was the Third Plenum of the $11^{\text {th }}$ Central Committee of the Chinese Communist Party which laid the roots for the re-emergence of entrepreneurship in China. This is because it emphasised individual incentives and economic development, (Liu, 2002). According to the latter until mid-1988 the main component of the private sector was the getihu or the individual household unit. However, at that time the government issued the Tentative Stipulations on Private Enterprise (TSPE). The TSPE stipulated that if a unit with private assets hired more than eight workers than it would be recognised as a private enterprise or saying qiye. Furthermore, the TSPE classified private enterprise in three ways, (Liu, 2002). These included sole ownership, partnership and limited liability corporations. However, in addition to the well-known forms of private enterprise, China's economy gave rise to additional forms of private enterprise. These included the red hat firm, the rented collective, the share-holding firm and the foreign investor joint enterprise, (Liu, 2002). The red hat firm obtained a licence from local government for production; and paid a percentage of its output value or turnover as a fee. Town and Village Enterprises, Urban Collective Enterprises and State Owned Enterprises were red hat firms. Rented collectives were collectives which were rented out to private enterprise. These types of firms were collective only in name as they operated according to the private sector mechanism in terms of generating profits. In a shareholding firm, shares in the collective assets of firms are distributed to employees and a share of the profits are distributed to workers as a bonus. Some state-owned enterprises have been privatised in this way and the evolution of Town and Village Enterprises from collectives as also taken the same route, (Liu, 2002). The last form of enterprise was the foreign investor joint enterprise. Foreign investors and firms investing in China were required to form joint ventures with a Chinese firm with tax advantage incentives. In order to take advantage of this, Chinese entrepreneurs registered offshore accounts to invest in China as foreign investors. In order to facilitate the transition to a market economy and entrepreneurship, the Chinese government also improved the legal framework by enacting the Company Law in 1993, followed by amendment in 1999, the Partnership Enterprise Law in 1997 and the Individual-Owned Enterprise Law in 1999, (Longbao, 2009). According to the latter, the government also enacted laws and regulations to improve the rights of parties to contracts, the payment of bills and the availability and the purchase of insurance. The legal system progressively also placed emphasis on ensuring fair competition, improving product quality and consumer protection, (Longbao, 2009). Nevertheless, the legal protection of personal assets and the legal enforcement of contracts in China is on a weak institutional footing, (Lu et al., 2007). According to the latter, this is in sharp contrast to advanced economies in which a strong and supportive institutional environment with regards to property rights and contract enforcement leads to only the personal attributes of the entrepreneur being the limit to the extent and the nature of entrepreneurship. The lack of a solid institutional footing in China suggests that the levels of individual creativity and entrepreneurship are constrained. And, from a wider perspective the country's rote learning educational system, reform of which has been attempted, also plays a role in constraining creativity in general.

The decollectivisation of agriculture, in the reform period, led to rising unemployment in the rural sector. As a result, this led to a stronger role for Town and Village Enterprises or TVE's. The latter were collectively owned by local governments and the workers while not being owned by the state itself. The output of the TVE's contributed to twenty percent of China's gross output by the 1990's, (Liao et al., 2001). In comparison on the state-owned enterprises, the operation of the TVE's reflected the flexibility of its managers to control production and distribution of goods and services in order to maintain low costs and price levels which would best promote the profitability of the enterprise. The focus of the managers of TVE's on profitability, in contrast to the managers of SOE's, would suggest that they represent the roots of modern entrepreneurship in China, (Liao et al., 2001). Nevertheless, in the 1980's institutional and resource constraints restricted the growth of entrepreneurship in China. The institutional constraint was represented by a law which restricted the number of employees of a private enterprise to just seven. In India a firm with more than 10 workers became part of the formal sector. In addition to human capital constraints in China, the resource constraint was represented by the lack of availability of funding to entrepreneurs. This was mainly due to the low level of savings, in banks, in China as well as the discriminatory behaviour of the state banks in restricting lending to just state owned enterprises. Furthermore, private enterprises complain of the frustration in dealing with state owned banks as 
well as the problems which arise from having to deal with corrupt government officials, Kshetri (2007). However, the government perception of the role of private enterprise changed with the realisation that state owned enterprises were inefficient with regards to the allocation of the factors of production and with the production of goods and services. The realisation of the inefficiency of state owned enterprises and the repeal of the law limiting the number of employees of private enterprises to seven signalled the state's shift towards recognising the importance of private enterprise to the Chinese economy.

In the post-economic reform period, the emergence of several types of entrepreneurship can be identified, (Liao et al., 2001). According to the latter, the first type of what could be loosely called entrepreneurs were street vendors providing retail and services who emerged prior to the 1978 economic reforms but persisted after the reforms progressed. Street vendors were self-employed and often were associated with illegal emigrants or those who either had a criminal background or low levels of education, (Liao et al., 2001). These street vendors, self-employed 'entrepreneurs' were effectively shut out of the state system and they earned enough to barely survive. The second type of entrepreneur emerged during the reform period and they can be characterised as being educated and having managerial experience with state owned enterprises. They operated in all sectors of the economy on a large scale in businesses known as 'siying qiye' which supplied state owned enterprises with intermediate goods. The third type of entrepreneurship in China can be associated with foreign educated or trained Chinese returning to China to set up businesses mainly in the Internet sector, (Liao et al., 2001). There are also a number of barriers in China which have a tendency to constrain entrepreneurial emergence and activity. These barriers include political and legal uncertainty, access to resources and cultural perception. Political and legal uncertainty arose due to the infancy of property rights and the rule of law. For example, in the context of gender and entrepreneurship, Deng et al (2011) find that a law of gender equality will fill an institutional gap which would allow female entrepreneurs in China to 'emerge on a solid footing'. Another strand of political and legal uncertainty may be the conflict of the objectives of central and provincial governments as well as the change of leadership at the top of the Communist Party. Access to alternative sources of resources, mainly finance, is constrained by the Confucian belief in self-sufficiency within the family. However, according to Krug et al (2002) because China represents a 'new market' in which entrepreneurs face high transactions costs associated with 'start-up' know; and insecurity due to developing institutions, such as property rights and business protocol, entrepreneurship occurs through a process of 'experimentation' and 'selection' on the basis of performance. According to Krug et al (2002) 'experimentation' and 'selection' explain why the family is no longer the basis of entrepreneurship in China, why networks are assessed on performance potential; and as to why Chinese firms may not care about developing a core business. The uncertain environment created by the transition of the Chinese economy from a command economy to a socialist market economy has created a number of uncertainties associated with property rights, the image of the entrepreneur and legal institutions themselves. This gap in business confidence created by an uncertain business environment has been filled by the emergence of Guanxi, (Kshetri, 2007). Business confidence may also be spurred by knowledge spillovers. For example, according to Kshetri (2007) overseas Chinese returning to China are bringing new business knowledge and skills associated with the western entrepreneurial style.

The traditional role of the Chinese family in entrepreneurship is that entrepreneurs in China prefer to draw on the savings of family members rather than to borrow from willing state owned banks or venture capital funds. Nevertheless, when entrepreneurs are able to 'tap' venture capital funds, social capital plays an important role, (Batjargal et al., 2004). This social capital can be considered to be similar if not the same as the Chinese social phenomenon of guanxi. In this case, networked relationships play a very important role in entrepreneurship in China. Parties to a business transaction which has resulted in a beneficial result for both parties ensure that the positive experience of both parties will allow them to not only transact again but also to act as 'recommenders' to third parties. This is the process by which the guanxi network established. The advantages of doing business by experience can be associated with each party having more information about how the other party behaves. This allows trust to be established between the two parties. Better information and greater trust allows for better business decisions leading to a more efficient allocation of the factors of production. In the case of venture capital, through better information and greater trust, investors can conduct thorough due-diligence tests. This will result in a more accurate valuation of the business they are investing in, (Batjargal et al., 2004). Guanxi thus reduces the uncertainty around the behaviour of investors and entrepreneurs. However, in Italy it has been found that the size of the initial investment in a new venture is not affected by the perceived uncertainty associated with the investment, (De Marco, 2000). On the other hand, the latter suggests that the size of the initial investment does affect the sales growth rates of the new venture.

According to Huang (2008) the phenomenal growth of the private sector can be explained by access to financial resources through foreign direct investment which permeated all sectors of the Chinese economy as a direct result of the economic reforms. Another constraint on entrepreneurship is access to resources such as labour. Chinese graduates lack work place skills; and risk averse peasants prefer to stay with inefficient state owned enterprises if they can, (Liao et al., 2001). According to the latter, the third constraint to entrepreneurship in China is the cultural perception that entrepreneurship is of low status. However, there was also political 
contempt of private enterprise which has a tendency to restrict their activities, Huang (2008). Nevertheless, Kirby et al. (1995) analysed the overlap between Chinese cultural values and generalised entrepreneurial values and found overlap with regards to perseverance, resourcefulness and diligence. However, profit orientation, change and initiative were in conflict with traditional Chinese cultural values. Holt (1997) found that due to the assiduous constraints faced by entrepreneurs in China, they were more risk tolerant than were entrepreneurs in the US. Culturally, the Chinese place greater emphasis on fate than do their western counterparts. This implies that Chinese entrepreneurship may benefit from a long-term strategy and opportunism, (Liao et al., 2001). On the other hand, another study has found that Chinese and Russian entrepreneurs had childhood friends and family members who were also entrepreneurs, (Djankov et al., 2006). Furthermore, Djankov et al (2006) also find that Russian and Chinese entrepreneurs valued work related activities more than leisure activities; and they also placed emphasis on the accumulation of wealth. The finding by Holt (1997) that Chinese entrepreneurs are more risk seeking compared to their US counterparts is similar to the findings of Djankov et al (2006) that Chinese entrepreneurs are also more risk seeking than are their Russian counterparts. Nevertheless, whereas Russian entrepreneurs are better educated than are Chinese entrepreneurs, Chinese entrepreneurs have more family members and childhood friends who are also entrepreneurs, (Djankov et al., 2006). Thus, Chinese entrepreneurs may emerge through spillover effects associated with entrepreneurial knowledge. At an intuitive level it would seem that people in China who become entrepreneurs do so because of a lack of access to good jobs due to their low/no level of education. It could be because of this that Chinese entrepreneurs are also more risk seeking than are entrepreneurs in either Russia or the US. It is due to the economic reforms in China that have led to the emergence of entrepreneurial opportunities which have been seized by Chinese entrepreneurs who lacked access to secure well paid jobs due to a poor education and due to a declining and inefficient state sector.

\section{Changes in Firm Ownership in China}

Since the late 1970's China's labour market has shifted from a centrally planned one to a market which is increasingly being driven by market forces, Meng (2012). One consequence of this is that, as can be seen from Figure 1 below, is that the proportion of workers employed in Primary Industry has been volatile between 1952 to 2012. But the trend in employment in Primary Industry has been downward and the fall in employment in the Primary Industry has been balanced by an increase in the number of workers employed in Secondary and Tertiary Industry. While the number of workers in Secondary and Tertiary Industry in the period 1952 to 1978 was relatively low compared to the number of workers employed in Primary Industry, after 1978 this changed. Furthermore, after 2002 the number of workers employed in Primary Industry began to fall while the number of workers employed in Secondary and Tertiary Industry began to rise. Employment in the Secondary and Tertiary Industry began to absorb the workers who had left employment in the Primary Industry more significantly after 2002.

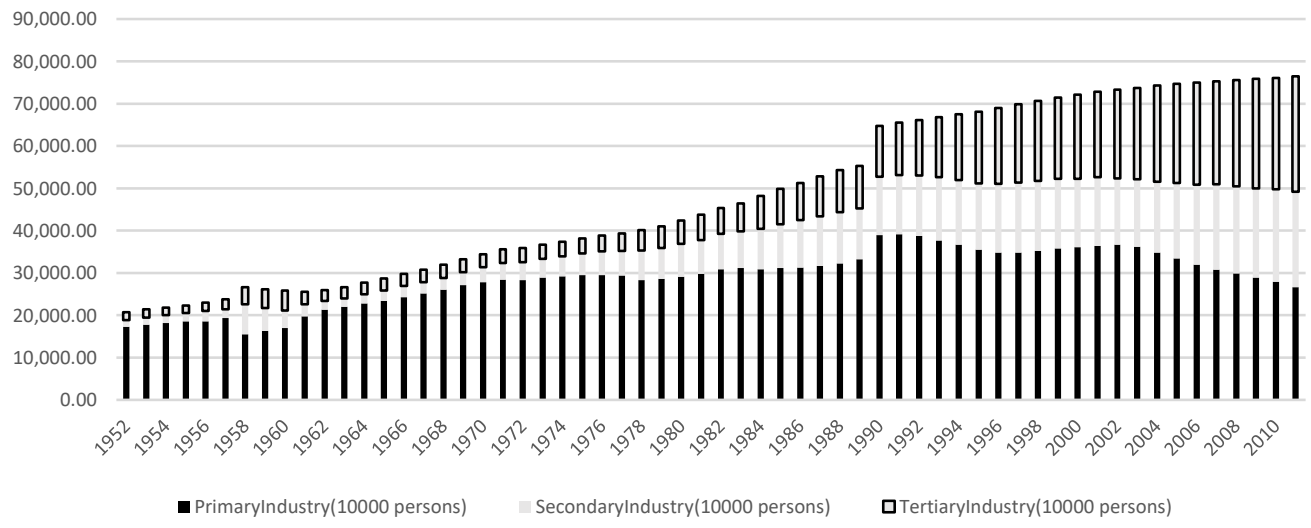

Figure 1: Employment in China's Primary, Secondary and Tertiary Industry: 1952 - 2012

Source: Chinese Bureau of National Statistics

However, the trend in employment in the Secondary and Tertiary Industry was upwards after 1978, only after 2002 did employment levels in Primary Industry show a downward trend. Before 1978 up to 80\% of workers were employed in the agricultural sector, which comprises Primary Industry, in China in farms organised as collectives or communes which provided a basic level of health, education and pensions to workers, Meng (2012). 


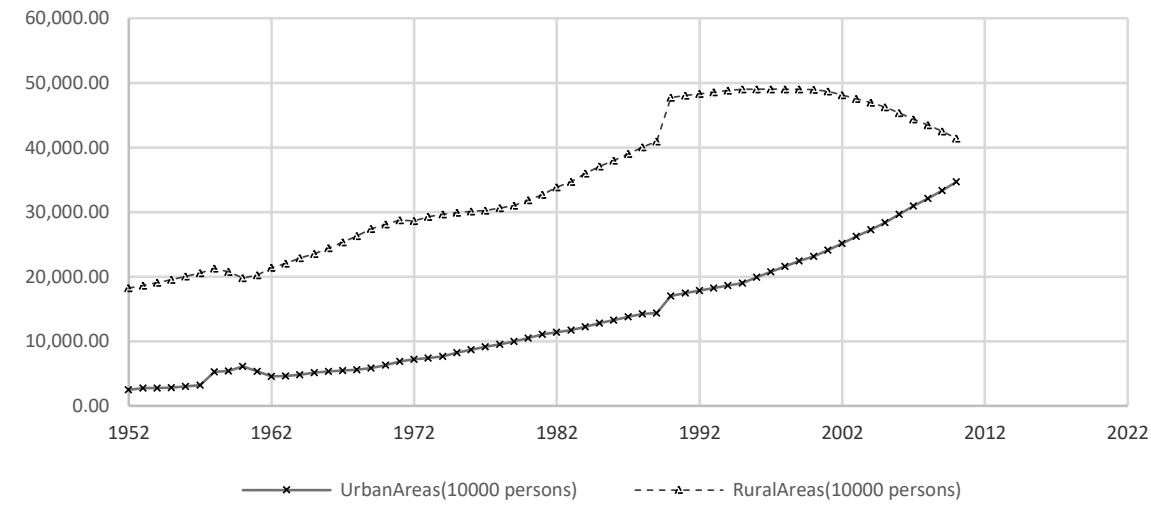

Figure 2: Employment in Urban and Rural Areas of China: 1952 to 2010 Source: Chinese Bureau of National Statistics

The reason for this that the government wanted to ensure that food was plentiful in supply to the cities. Rural to urban migration was severely constrained by the Hukou System, Meng (2012). In the urban sector the country's central planners ensured that city dwellers had life time employment with centrally planned wages as well as a cradle to grave welfare system. China's economic reforms impacted on the country's rural sector first followed by the urban sector. Reforms in the rural sector boosted agricultural productivity but by the mid-1980's underemployment in the agricultural sector had become a serious problem and workers were encouraged to set up Township and Village Enterprises, Meng (2012). By the mid-1990's workers in the state owned urban sector began to be made redundant due to the governments restructuring of state owned enterprises and the emergence of the private sector, Meng (2012). Necessity based entrepreneurship may have increased; and there was convergence between rural and urban employment levels, as can be seen from Figure 2, above.

There are a number of interesting features which characterise the Chinese labour markets transition from a centrally planned one to one based on market forces besides the traditional distinction between rural and urban labour, Fields et al (2013). Firstly, the Chinese labour market became increasingly segmented between state, private and agricultural employment.

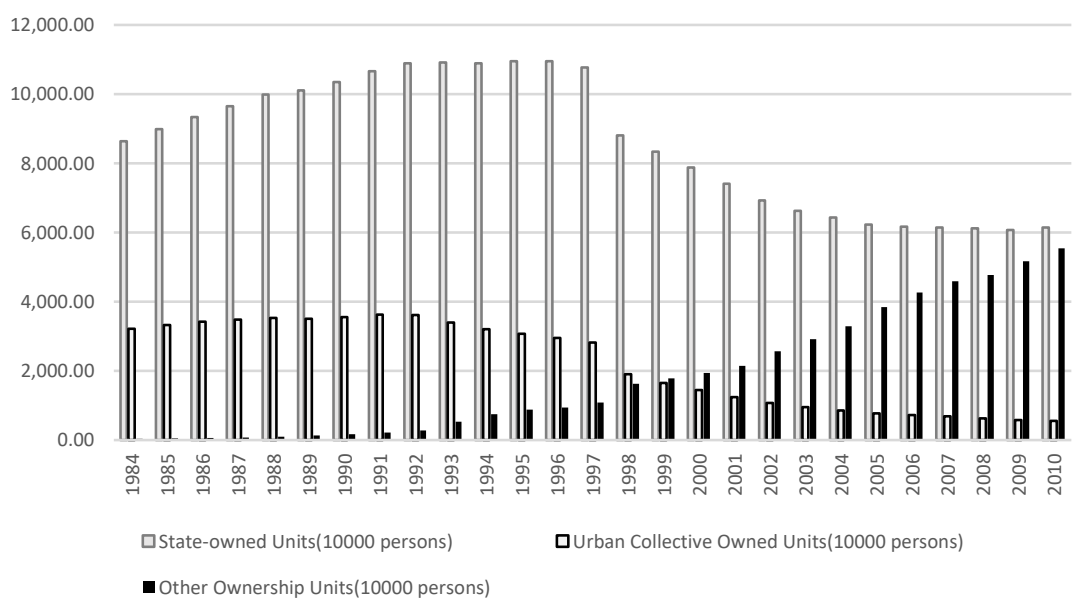

Figure 3: Change in Firm Ownership: 1984 to 2010.

Source: Chinese Bureau of National Statistics

The change in the Chinese labour market from a centrally planned one to one which is increasingly underpinned by market forces can also be seen from the way in which firm ownership has changed in China over the reform years. Secondly, the increasing effect of the operation of market forces in China may be evidenced by increasing wage levels, Li et al (2012). However, increasing wages in the Chinese labour market may also be evidenced by increasing employer costs due to government labour legislation, Ramesh (2012). Figure 3, above shows the change in firm ownership in China from 1984 to 2010 between state ownership, urban collective owned and other ownership types. It can be clearly seen from Figure 10.2 that between 1984 and 1999 that state ownership 
of firms and urban collective owned units was more dominant than other types of firm ownership. However, after 1999 other ownership of firms began to increase while state ownership and urban collective ownership of firms began to decline. By 2000, other ownership of firms had overtaken urban collective ownership with the former becoming comparable to state ownership by 2010. Thirdly, the Hukou worker registration system which maintained the rural-urban divide became increasingly flexible as millions of rural Chinese migrated to the urban regions to find work. Finally, there was a shift from less employment in the rural sector to more employment in the urban sector, as can be seen from Figure 2 above. Despite the previous discussion on how the Chinese labour market could be segmented: the urban labour market can itself be segmented into three types of workers, Appleton et al (2004). Firstly, the recently retrenched and reemployed urban workers. Secondly, the non-retrenched urban workers. And finally, rural to urban migrants. Although the Hukou system is more flexible today than it has ever been it still continues to play a role in the Chinese labour market, Fields et al (2013). China's labour market transition also meant that increasingly workers were able to select the employers they wanted to work for and employers were left to hire and fire workers as they liked. At a demographic level the young and the old have seen reductions in employment levels with no significant differences due to gender, Meng (2012). The transition of the Chinese labour market from a centrally planned one to one which functioned on market forces drew the attention of the central government in the early part of this century.

By 2003 the newly emerging leadership in China wanted to formulate the countries policies from three perspectives. These included social justice, social harmony and environmental protection, Cooke (2009). The first two signalled the protection of the rights of workers and employers through increasing regulation of the Chinese labour market. Three new laws which would affect the Chinese labour market came into effect in 2008, Cooke (2009). These were the first since the Labour Law enacted in 1995; and included the Labour Contract Law, the Employment Promotion Law and the Labour Dispute Mediation and Arbitration Law. The Labour Contract Law set out to delineate the rights and responsibilities of workers and employers. The Employment Promotion Law sought to strengthen worker employment and rights. And, the Labour Dispute Mediation and Arbitration Law sought to ensure the fulfilment of the rights of workers and employers enshrined in the Labour Contract Law.

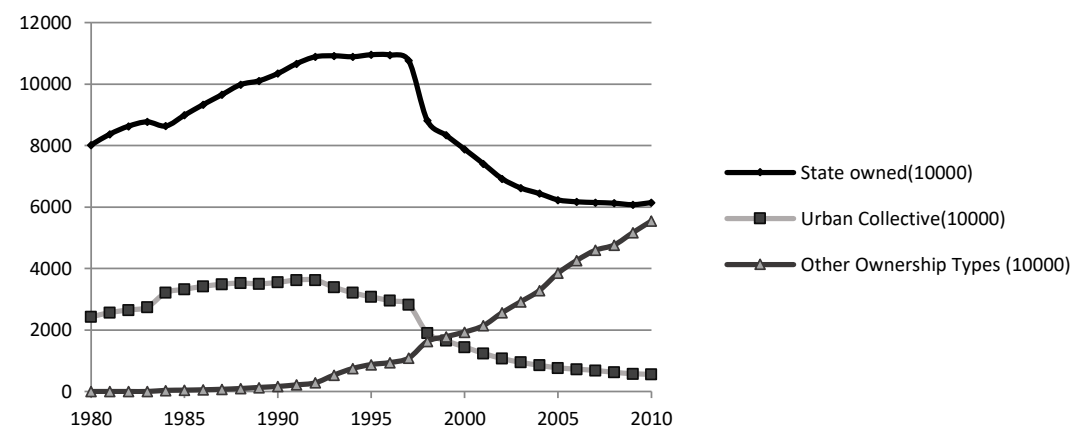

Figure 4: Employees by Enterprise Type - 1980 to 2010

Source: Chinese Bureau of National Statistics

Figure 4 shows the changing nature of the number of employees by enterprise type from 1980 to 2010 . It can be clearly seen that especially after 1997, the number of employees by other ownership types of enterprise is on the rise while the number of employees by state owned and urban collective enterprises is decreasing.

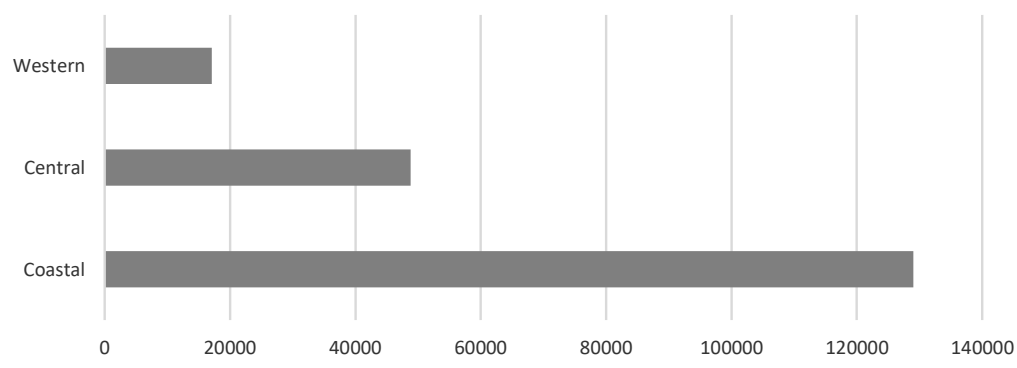

Figure 4: Private Industrial Enterprises by Region 2013

Source: National Bureau of Statistics, China Statistical Survey 2014 
Figure 4, above shows the number of private industrial enterprises by region for China in 2013. In descending order it can be seen that, the Coastal region has the greatest number of such enterprises followed by the Central and then the Western region. The number of private enterprises in the Coastal region is almost three times the number of such enterprises in the Central region.

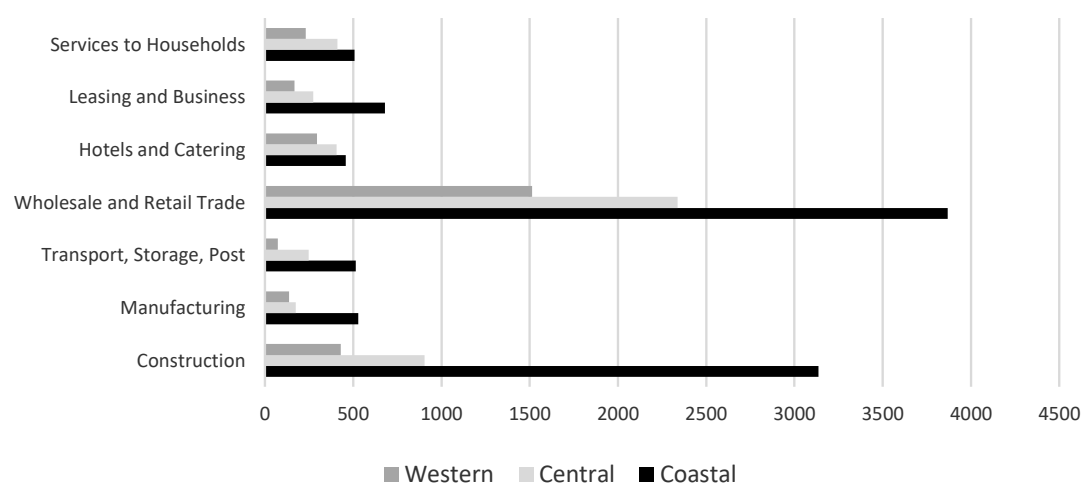

Figure 5: Persons* in Private Enterprises/Self-Employed Individuals by Region (2012)

Source: National Bureau of Statistics, China Statistical Survey 2013

Notes: *10000 persons

On the other hand, the Central region has just over twice the number of private enterprises found in the Western region of China. This would suggest that the economic reforms which started in China's Coastal region helped entrepreneurship to embed and grow more in that region than in either the Central or the Western regions of China. Figure 5, above shows the number of persons either employed by private enterprises or self-employed by region in China for 2012. It can be clearly seen that the Coastal region has more persons self-employed or employed by enterprise in any sector in any region comparison to the either the Central or the Western regions. Furthermore, construction and wholesale and retail trade are by far the largest in the Coastal region compared to either the Central or to the Western regions.

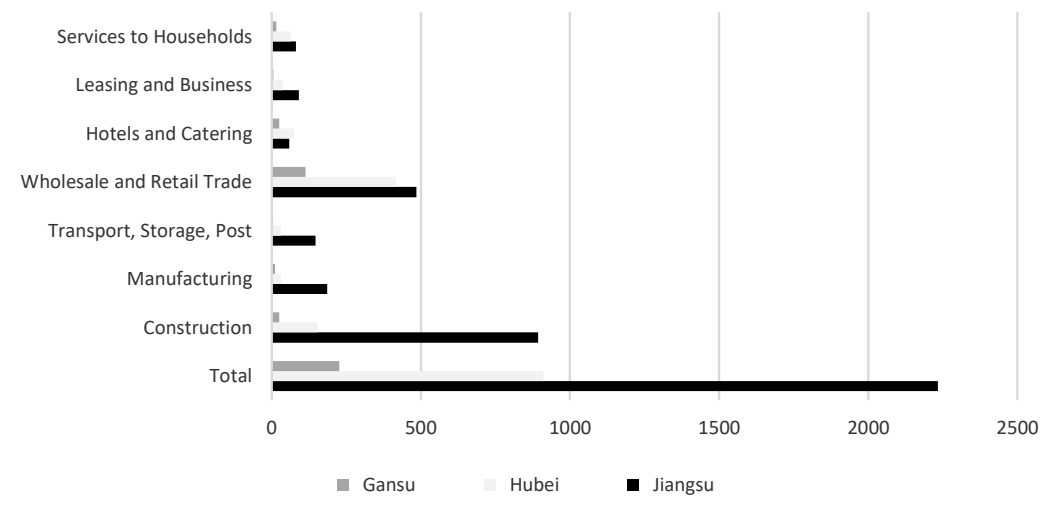

Figure 6: Persons* in Private Enterprises/Self-Employed Individuals by Province (2012)

Source: National Bureau of Statistics, China Statistical Survey 2013

Notes: *10000 persons

The findings of Figure 5 at a regional level are mirrored at a provincial level as shown by Figure 6 which shows that Jiangsu, a Coastal province, has more people who are either self-employed or employed by private enterprises than does either Hubei, a Central province, or Gansu, a Western province. This is specifically true in the context of wholesale and retail trade and construction. Furthermore, at a provincial level it becomes clear that the number of person's self-employed or employed in private enterprises in manufacturing in Jiangsu overshadows the numbers employed in that sector in either Hubei or in Gansu. This finding reiterates previously established evidence that China's economic reforms have embedded secondary and tertiary level activities such as manufacturing, wholesale and retail trade and construction in China's Coastal region. It logically follows that more manufacturing would lead to more imports and exports and increasing wholesale and retail trade. The result would be that Gross Regional Product is on the rise and as a result increasing provincial affluence and 
increased economic activity will lead to more construction. In 2007 the government launched the $11^{\text {th }}$ Five Year Plan for western economic development. At the heart of the plan was the establishment of economic zones in Chengdu-Chongqing, Guanzhong-Tianshui and Guangxi Northern Gulf areas. The idea behind the establishment of these economic zones was to make use of these geographical areas natural resources, industrial capacity, urban development and labour supply in order to allow enterprise to increase the productivity in the zones. It is hoped that the establishment of these economic zones will allow the Western region to economically develop as rapidly as did Chinese Coastal region through the establishment of economic zones in the Yangtze River Delta (YRD), the Pearl River Delta (PRD) and the Beijing-Tianjin-Hebei Metropolitan Area (BTHMA). The YRD focused on technological and manufacturing industries, the PRD focused on various manufacturing industries, the BTHMA on petroleum and natural gas exploitation; and the production of electronic equipment, publishing and printing equipment and communications equipment, (Longbao, 2009).

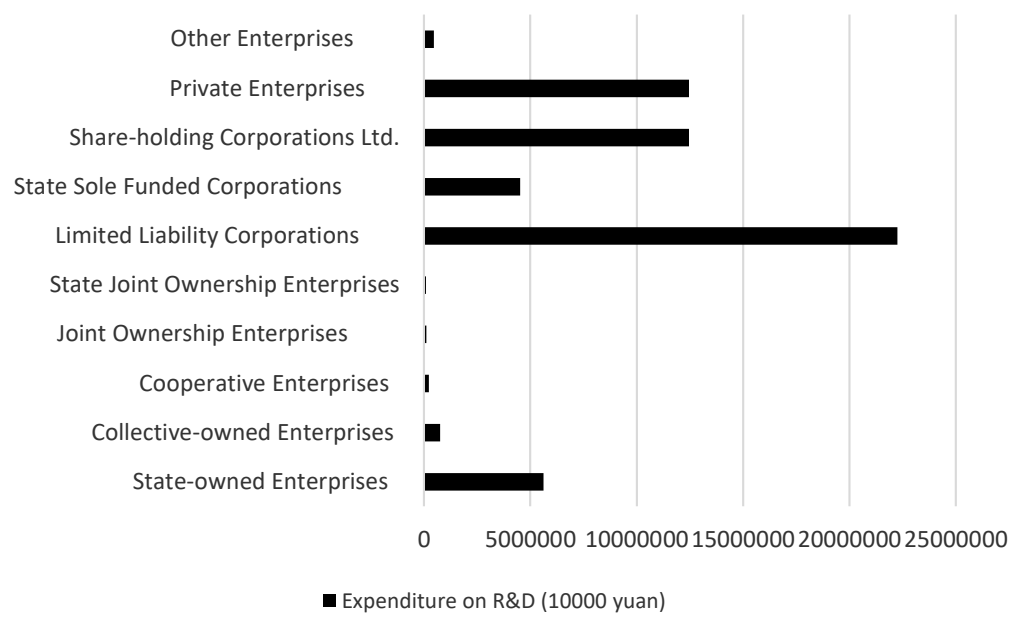

Figure 7: R\&D Expenditure by Firm Ownership (2012)

Source: National Bureau of Statistics, China Statistical Survey 2013

Figure 7, above shows R\&D expenditure by firm ownership type in 2012. In this case, it can be seen that those firms which are independent of the state in terms of funding and more reliant on market forces tend to be the most innovative as measured by the amount spent on R\&D. Thus, private enterprises, share-holding corporations and limited liability corporations have spent more money on R\&D than has been spent on R\&D by state owned enterprises. Firms which are not dependent on state funding for day to day operations and more dependent on market forces compete for revenue and market share. Moreover, the managers of these firms are also likely to be more risk seeking than are their counterparts in state owned firms.

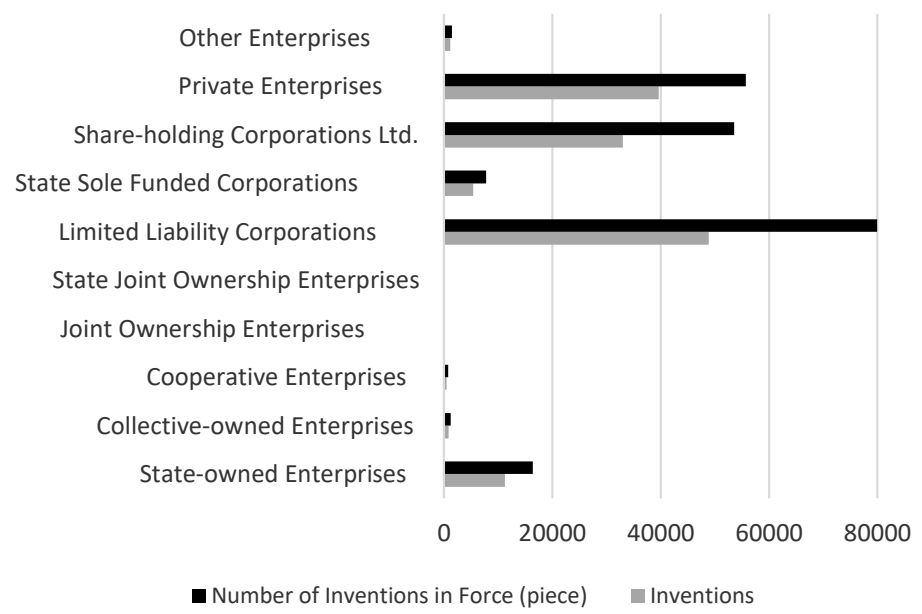

Figure 8: Number of Inventions Patents and Inventions by Enterprise Type (2012)

Source: National Bureau of Statistics, China Statistical Survey 2013

As such any competitive advantage which may arise to these firms is dependent on the innovativeness of the firms. The greater the amount of money which each firm will spend on innovation, through R\&D expenditure, 
then the bigger will be the potential to innovate and develop new products and processes. Firms which are innovative, develop new products and processes are likely to capture market share and sales from firms which are less innovative. However, state owned enterprises do not need to compete to survive as they receive state funding in order to ensure their day to day operational survival. Such firms will have less incentive to use R\&D money provided by the government efficiently because of the problem of moral hazard. In other words, the government will always be at hand in order to supply more R\&D funding if the state-owned enterprise runs out of money and needs more money. This type of government expenditure is wasteful and tends to act as a 'drag' on the effectiveness of central government funding.

Figure 8, above shows the number of inventions and patents and inventions by enterprise type for 2012. The number of inventions in force are those inventions for which the firms have a patent. Inventions may be those inventions for which the firm has applied for a patent. It can be clearly seen from Figure 10.8 that nonstate owned enterprises are more innovative, as measured by the number of inventions in force and the number of inventions compared to state owned enterprises. Amongst the non-state enterprises, limited liability corporations have the most number of inventions in force as well as the number of inventions in comparison to either private enterprises or shareholding corporations. However, private enterprises had slightly more number of inventions in force as well as slightly more inventions compared to shareholding corporations. On the other hand, state owned enterprises have a much smaller number of inventions in force as well as a lower number of inventions. This finding gives some credibility to the idea that state owned enterprises do not need to be competitively efficient to survive. It's perhaps because of this that state owned enterprises have a far smaller amount allocated to R\&D expenditure in comparison to private enterprises, shareholding corporations or limited liability corporations. The low levels of $\mathrm{R} \& \mathrm{D}$ expenditure by state owned enterprises could also suggest that state owned enterprises have less financial resources available in comparison to other firm types especially private enterprises, shareholding corporations and limited liability corporations. Yiu et al (2008) empirically show that the generation of profits from networked resources is due to the mediating effects of corporate entrepreneurship.

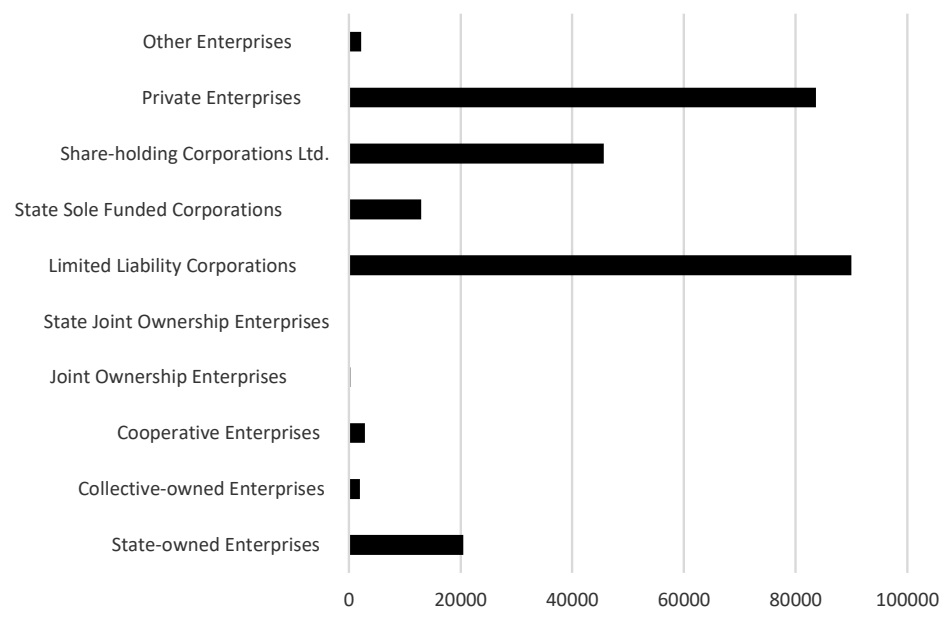

Figure 9: Number of New Products by Enterprise Type (2012)

Source: National Bureau of Statistics, China Statistical Survey 2013

The view that market oriented, and therefore more entrepreneurial firms in China are more likely to be innovative than are state owned enterprises is supported by the data shown in Figure 9, above. In this case, it can be clearly seen from Figure 9 that private enterprises, shareholding corporations and limited liability corporations had a greater output in 2012 than did either state sole funded enterprises or state-owned enterprises. Furthermore, the new product output of limited liability corporations and private enterprises is over three times the output of state owned enterprises. While the new product output of shareholding corporations is just over twice the new product output of state owned enterprises. This indicates that new product development by shareholding corporations maybe hindered by ownership limits on borrowing and/or smaller profits being available for R\&D expenditure. In this case, a large proportion of a shareholding corporation's profits may be distributed away to shareholders as dividend, On the other hand, the new product output of limited liability corporations is slightly greater than is the new product output of private enterprises. These two firm types may have access to more funds either by being able to borrow more or due to larger profits, allowing them to finance a higher level of R\&D expenditure in comparison to either state owned enterprises or too shareholding corporations. The greater funds accessible for R\&D expenditure then the greater will be the level of new product 
innovation by the firms. However, an interesting finding is that shareholding corporations generate more revenue from the sales of its new products than do private enterprises. This is in contrast to the finding that private enterprises produce more new products than do shareholding corporations. One explanation of this paradox is that shareholding corporations may produce a small number of high value new products, while private enterprises produce a large number of low value new products. However, limited liability corporations still generate the most sales revenue from new products in comparison to the sales revenue generated by either private enterprises, shareholding corporations or state owned enterprises. This can be seen from Figure 10 below.

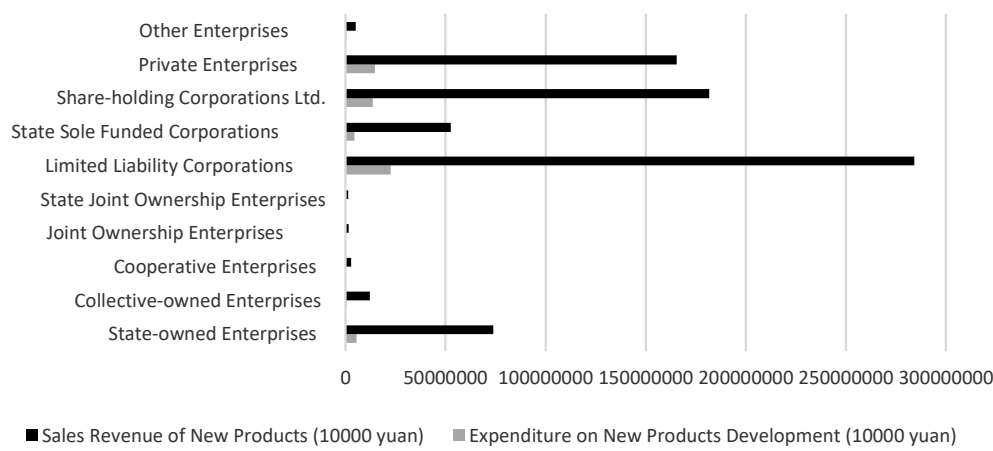

Figure 10: Sales Revenue/Expenditure of New Products by Enterprise Type (2012) Source: National Bureau of Statistics, China Statistical Survey 2013

The results of the comparison of the sales revenue generated domestically by private enterprise, shareholding corporations, limited liability corporations and state-owned enterprises is mirrored in the data for export value of new products by enterprise type for 2012 as shown in Figure 11, below.

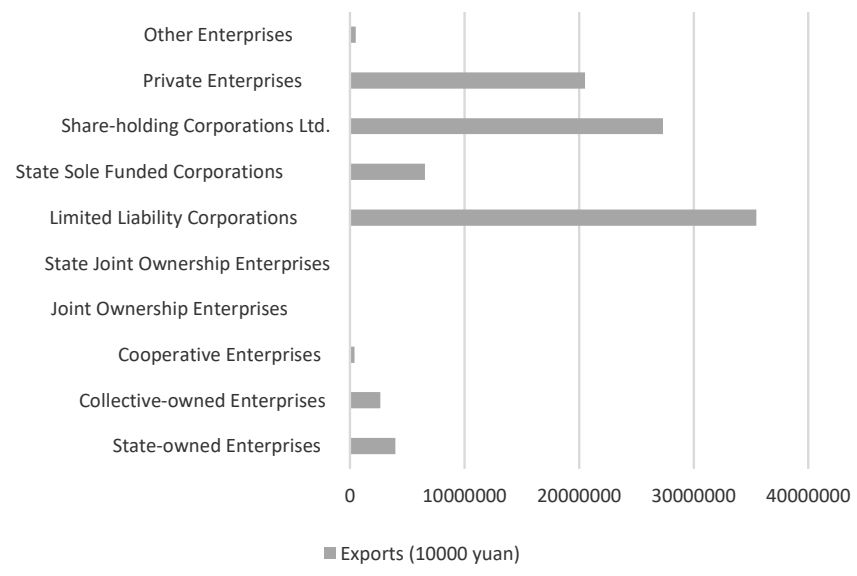

Figure 11: Export Value of New Products by Enterprise Type (2012)

Source: National Bureau of Statistics, China Statistical Survey 2013

The export value of new products is greater in descending order for limited liability corporations, shareholding corporations and private enterprises. In contrast the export value generated by the sales of new products for state owned enterprises is by far much smaller in comparison to that generated by the three other types of firm ownership, private enterprises, limited liability corporations or shareholding corporations. China's economic growth since 1978 has been based on a manufacturing led export strategy. Naude and Rossouw (2010) conducted an analysis of the nature and of the determinants of early entrepreneurship in China based on data from the World Bank's Investment Climate Private Enterprise Survey of 3948 Chinese private sector firms in 2002 and in 2003. The findings of the analysis by Naude and Rossouw (2010) suggests that firms in China which export tend to:

a) Directly export without the need for intermediaries,

b) Be bigger than firms which do not export,

c) Displayed much faster growth than forms which did not export,

d) Be younger than firms which did not export, 
e) Develop new products at a faster rate as a result of a higher level of R\&D expenditure.

f) Employ more managers with an international background as well as having more foreign ownership/shareholding.

Since Chinese economic growth has been driven by the export of light manufactured goods, facilitating more entrepreneurial activity in the development of exporting firms is an important policy objective. Furthermore, the importance of this policy objective is underlined by the fact that a number of positive spillovers can be associated with the activities of exporting firms and their value creating activities. These positive spillovers include increases in firm size and employment numbers, learning by doing and accumulating experience, the transfer of knowledge and technology due to foreign ownership as well as the indirect benefits of R\&D, (Naude et al., 2010). In this regard, a single R\&D project could lead to multiple sources of innovation.

Chinese technological entrepreneurship has been facilitated by government initiatives such as the Torch Program which was initiated in 1988. The motives for the development of the Torch Program was to foster the development of institutions which would generate indigenous innovation and technological innovation, (Yu et al., 2009). The latter suggests that the main contribution of the Torch Program to China's innovation system were the science parks; and business incubators, also known as high tech innovation centres. Whereas China's technological entrepreneurship policies were modelled on other western and other countries innovation programs, they deviated in a number of ways, (Yu et al., 2009). Firstly, innovation policy tended to drift with the requirements of central government macroeconomic policies. Secondly, innovation policies at the provincial level were influenced by local officials in association with local stakeholders. Lastly, science parks in China combined manufacturing with technological innovation whereas in western countries the focus of science park policy was the integration of research and development with education and the needs of industry. In the context of manufacturing given the fact that young firms tend to export more than do older firms, policymakers should focus on facilitating policies which 'enable, motivate, mediate and moderate factors' which allow firms to export sooner rather than later, (Naude et al., 2010). Nevertheless, allied to such policies the policymakers should ensure that the market is competitive in order to allow more firms to enter the market. As a result firms are not only efficient and healthy but also innovative. Furthermore, Alon et al (2008) found that that the higher the number of projected employees of the firm; and the greater the educational and skill level of Chinese entrepreneurs then the greater the likelihood of international exposure. Nevertheless, risk averse behaviour of Chinese entrepreneurs and lack of competition in the Chinese market would reduce the likelihood of Chinese private enterprises international exposure, (Alon et al., 2008).

China's transition to an export led economy was facilitated by foreign enterprises setting up manufacturing operations in China. Three laws provided the legal framework which governed the way in which foreign enterprises interacted with China in the context of creating a favourable investment climate (Longbao, 2009). These laws included the Law on Joint Chinese and Foreign Investment Enterprises in 1979, the Law on Foreign Funded Enterprises and the Sino-foreign Cooperative Joint Venture Law. According to Longbao (2009), foreign entrepreneurship and foreign capital has contributed to China's economic development in five ways. These include increased employment, advances in technology through spillover effects due to foreign enterprises R\&D centres in China, increased industrial output, increased foreign trade and increased tax revenue for the government. However, the Chinese government was keen to be not to be dependent on foreign enterprises for the evolution of Chinese industry. In this case, the government implemented the Top Ten Industry Promotion Planning initiative in 2009, (Longbao, 2009). The initiative ran for two years and it allowed for increased industrial capacity and the upgrading of equipment, increasing technological innovation in order to improve global competitiveness. Longbao (2009) also suggests that the aim of this initiative was to strengthen indigenous Chinese industrial capacity in the production of automobiles, iron and steel, textile equipment, manufacturing, shipbuilding, electronic information, light industry, petrochemicals, non-ferrous metal and logistics.

\section{Entrepreneurship in India}

Figure 12, below shows that the percentage of total employment in the agricultural sector is $45 \%$, whereas the percentage of total employment in services is just over $26 \%$ while the percentage of total employment in industry is just over $20 \%$. These statistics clearly demonstrates that even today, in 2017 approximately $45 \%$ of India's workforce is still employed in the agriculture sector. This shows that the transition of employment from agriculture to industry has not occurred as fully as it did in China. This may have been due to the appropriation of agricultural surplus by the landowners with no benefit being derived by tenant farmers and agricultural workers from agricultural production. On the other hand, in China, the state appropriated agricultural surplus which was used to fund rural industrialisation from which rural agricultural workers were able to acquire skills which would be put to use in the reorientation of the economy towards industry following the commencement of the economic reforms of 1978. 


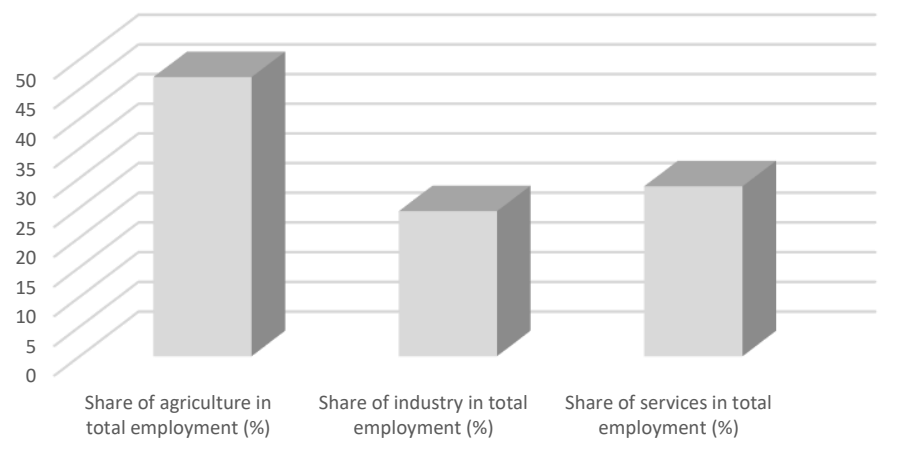

Figure 12: Percentage share of employment by primary, secondary and tertiary sector in India in 2017 Source: Compiled by author using IndiaStat

In India employment is predominantly provided by the public sector as opposed to the private sector.

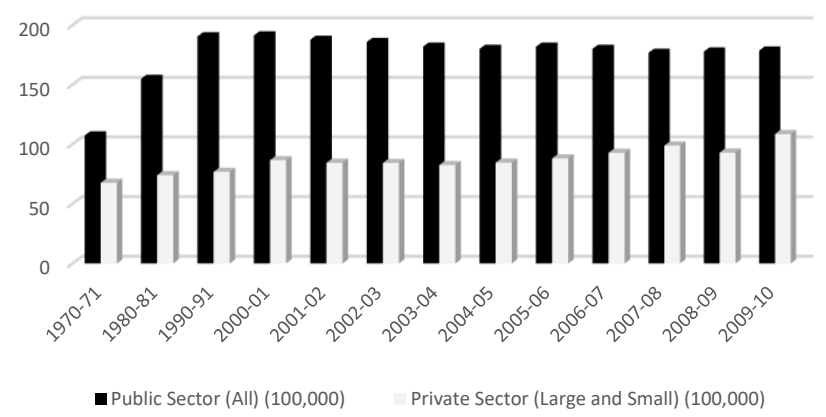

Figure 13: Estimated Employment in the Private and the Public Sector - 1970 to 2010

Source: Compiled by author using IndiaStat

This can be seen from Figure 13, above which shows the estimated employment in the private and in the public sector between 1970 and 2010. Since 1970, the public sector in India has always provided more jobs than as the private sector. However, while the trend in the number of jobs provided by the public sector has been falling over the years since 1990. This trend has not been big. Similarly, while the trend in the number of jobs provided by the private sector has been growing over time since 1970, this trend is most perceptible after 2004.

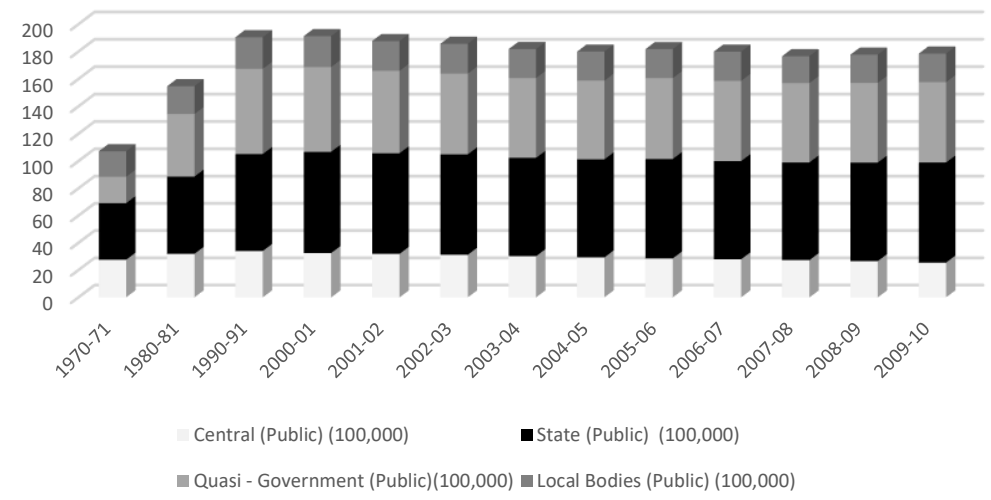

Figure 14: Estimated Employment in the Public Sector - 1970 to 2010

Source: Compiled by author using IndiaStat 
While it has been established that the public sector provides more jobs than the private sector in India, Figure 14 shows the composition of public sector jobs between 1970 and 2010. It can be clearly seen in Figure 14 that the central government composition of public sector jobs as only been $20 \%$ between 1970 to 2010 . This would mean that during this period $80 \%$ of public sector jobs were generated by a combination of state governments, quasi-government bodies and local bodies. Of these three composites, the biggest contributors to public sector employment are the states and quasi-government bodies.

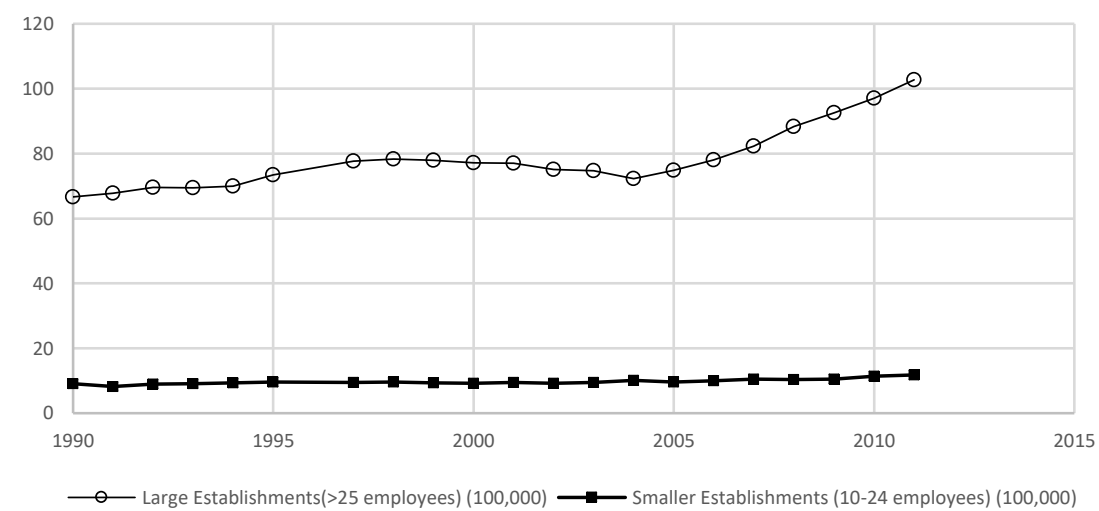

Figure 15: Estimated Employment in the Private Sector - 1990 to 2015

Source: Compiled by author using IndiaStat

While the number of jobs in the private sector has been growing relative to those in the public sector, the source of this growth lies with the increase in the number of large establishments, with over 25 employees, in comparison with smaller establishments which have 10 to 24 employees. The trend in the estimated employment in the private sector between 1990 and 2015 is shown in Figure 15, above. It can be seen that the biggest estimated component of private sector employment since 1990 has been large establishments in comparison to smaller establishments. In fact, the change in the estimated employment in the private sector due to smaller establishments as remained static in the twenty years from 1990. The estimated employment in the private sector due to large establishments increases substantially after 2004. This observation is supported by the data for estimated employment in the private sector in Figure 13.

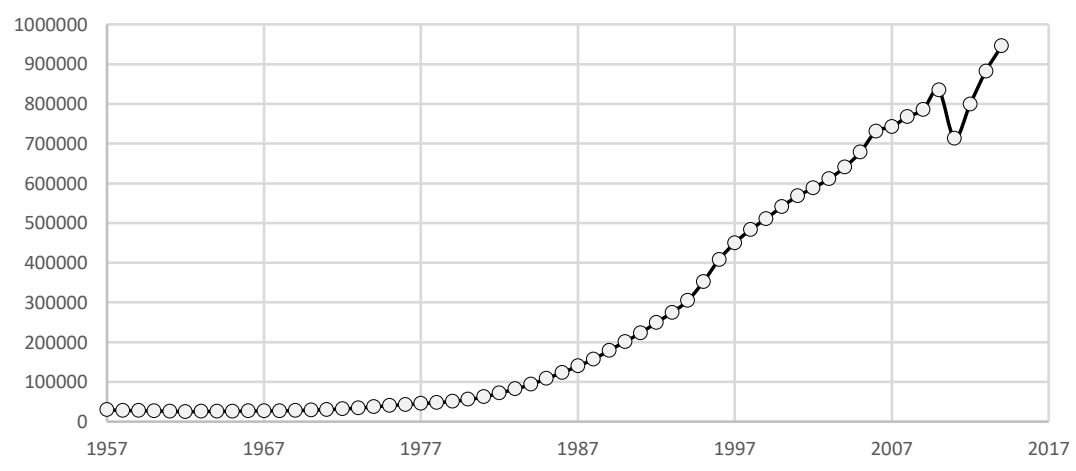

Figure 16: Number of non-government companies limited by share - 1957 - 2016 Source: Compiled by author using IndiaStat

The number of non-government companies limited by share from 1957 to 2016 began to increase after the limited economic reforms of the early 1980's with a more significant increase after the major economic reforms of the early 1990's. However, there was a dip in the number of non-government companies limited by share around the time of the aftermath of the global financial crisis in 2009/2010. This may have resulted in a slowdown in economic activity such that some companies limited by share went out of business and not many new companies registered. These trends in the number of non-government companies limited by share can be seen in Figure 16 above. On the basis of what has been discussed it becomes clear that the limited economic reforms of the early 1980's led to a limited increase in private sector enterprise. Nevertheless, the increase in private sector enterprise was more sustained after the broader range of economic reforms of the early 1990's. 
This may have been due to the higher probability of being able to make substantially more profits which incentivised entrepreneurs to establish companies limited by share.

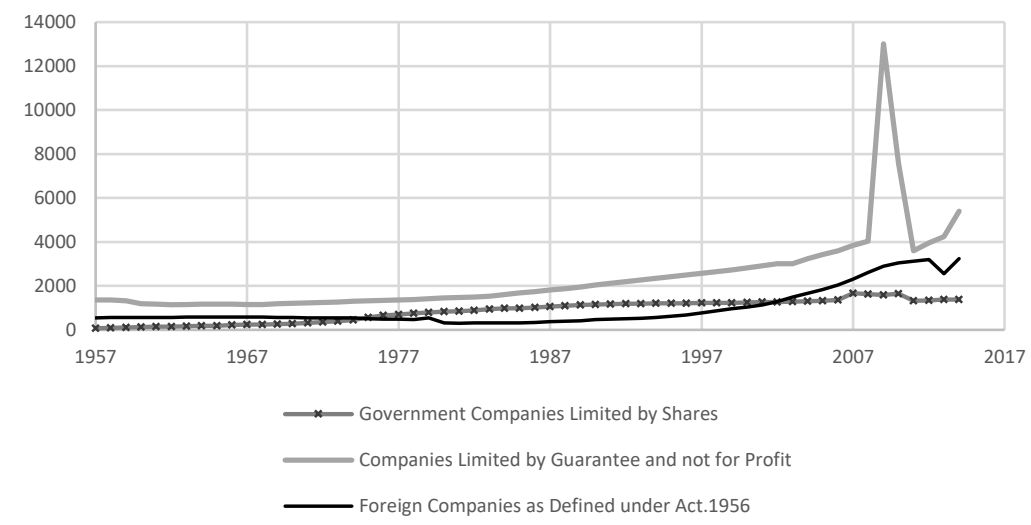

Figure 17: Number of government companies limited by share, companies limited by guarantee and foreign companies 1957 - 2016

Source: Compiled by author using IndiaStat

Of the three different types of companies, government companies limited by share, foreign companies; and companies limited by guarantee and not for profit, the latter as shown a sustained increase in numbers since the early 1980's and during and after the global financial crisis in 2008. These trends can be seen in Figure 17 above. However, after the late 1990's the trend in the number of foreign companies as defined under the Act of 1956 is noticeable upward though not substantially so. This may have been due to the easing of restrictions associated with investments by foreign companies in India.

\begin{tabular}{|c|c|c|c|}
\hline Type of Company & Government & Non-government & Total \\
\hline Public Limited & 1156 & 63,713 & 64869 \\
\hline Private & 462 & 1096850 & 1097312 \\
\hline One person Company & 0 & 10978 & 10978 \\
\hline
\end{tabular}

Table 18: Companies Limited by Shares in India - 2017 Source: Compiled by author using IndiaStat

Table 18 shows the data for the companies limited by share in India in 2017. In this case, it can be seen that private companies limited by share are by far the biggest category amongst the other two categories. However, the number of private companies limited by share in India is far smaller than the total number of private industrial enterprises by region in China as shown in Figure 4. This is further evidence to support the view that private enterprise and entrepreneurship has played a limited role as the dynamo of Indian economic growth in comparison to private enterprise and entrepreneurship as the dynamo of Chinese economic growth. The development of entrepreneurship in India and China as also followed different paths. However, in general institutional rigidity has hindered entrepreneurship while in China institutional dynamism has embraced it. In the pre-colonial and in the colonial period, in India, the trader merchant and the money lender represented the entrepreneurial class, embedded and held in place in society by a rigid caste system and by the Hindu religion which hinged on the philosophy of fate, (Swetha et al., 2013). According to the latter the history of entrepreneurship in India starts with the Indus Valley civilisation which forged trade links with Iran and with Central Asia. The types of entrepreneurial phases in India by historical period can be broken down into five distinct types, (Gupta, 2008). According to the latter these include the Panchayati Raj (pre-1700), the British Raj (1700-1950), the License Raj (1950 - 1985), the Jugaad Raj (1985 - 1995) and the Invisible Raj (1995 - 2010). The Panchayati Raj saw the emergence of village craft entrepreneurship and entrepreneurship at the local level. Trade in the village revolved around the barter system with the blacksmith being paid in agricultural produce. The British Raj saw the demise of village craft entrepreneurship and the artisan in India. An example would be India's hand looming village industry. This was due to the introduction of the modern factory system, (Medhora, 1965). India's textile exports to Britain were heavily taxed whereas Britain's textile exports to India were not. The result was a decline in India's textile industry. The British Raj also represented a hostile environment for 
Indian entrepreneurship, (Swetha et al., 2013). However, in pre-British India enterprise was limited to mainly money lending and trade due to low expectations of reward; and the occupational rigidity of the caste system, (Tripathi,1981).

A managing agency system emerged following the loss of monopoly trading rights by the British East India Company, (Brimmer, 1955). The managing agency system is unique to India; and it is one in which one firm manages the finance, promotion and the administration of other legally separate firms. The single controlling firm is the 'firm' as known in conventional Industrial Economics. It is the pervading form of economic organisation in industry, trade and in commercial agriculture, (Brimmer, 1955). Indian agency firms can take the form of private limited companies but are usually partnerships, in the context of family relationships and stratified by caste. According to Brimmer (1955) the managing agency system has legal roots in the Indian Companies Act 1913, as amended in 1936; and it evolved due to two reasons. Firstly, there was a shortage of venture capital in India. And secondly, there was a shortage of entrepreneurial capital in India. However, Indian managing agency firms were formed because the Indian owners had accumulated wealth through trade but lacked technical expertise in contrast to the British owners of managing agency firms in India. Furthermore, in contrast to the western experience of start-up innovation, risk taking and wealth creation in entrepreneurship remains limited in the Indian experience, (Jain, 2013).

A License Raj came into being in an independent India. One of the implications of the License Raj was that the public sector took control of major investments and India's economy became centrally planned. Under the License Raj, large private sector investments required licenses which were hard to get. However, under the License Raj two types of entrepreneurship flourished in India due to central government initiatives, (Gupta, 2008). These included farm and defence entrepreneurship. Farm entrepreneurship was the basis of the Green Revolution in India which allowed the country to escape the famine and starvation of the 1960's, (Gupta, 2008). Farming entrepreneurship was facilitated by state funding of R\&D in farming allied with capacity building due to extension networks which allowed Indian farmers to allow India to achieve self-sufficiency in food. Defence entrepreneurship was facilitated by the state 'borrowing' military technology from other countries and then extending capacity to local private entrepreneurs to develop and build Indian versions of the defence technology, (Gupta, 2008). The period 1985 to 1995 is often referred to as the Jugaad Raj. The relaxation of the License Raj led to the emergence of software developers and hardware designers and dealers from the educated professionals who emerged as a result of the License Raj, (Gupta, 2008). The shift in Indian economic policy from import substitution to market liberalisation, state sponsored development of the Software Technology Park in Bangalore in 1990; and the outsourcing of the development and design of software systems by MNC's to Indian firms such as Tata, Wipro and Infosys led to the emergence of local technological entrepreneurship, (Parthasarathy et al., 2006). According to the latter was the upgrading of the Indian software industry from the provision of low-skill software services to the provision of high skill R\&D services.

Despite the distinct phases of entrepreneurship in India, Medhora (1965) identifies two types of entrepreneurship by nature. Firstly, innovative entrepreneurship facilitates a dynamic economy. Secondly, an imitative entrepreneurship allows for spread effects of new products to a wider market. However, this would depend on the social and on the economic environment, (Medhora, 1965). In India the social environment is influenced by the Hindu religions segregation of Indian society by caste. In this case there are four main castes, the Brahmin or priest class, the Kshtriya or warrior class, the Vaishya or the trader class and the Shudra or the artisan class. While the caste system may lead to the immobility of labour it does not necessarily lead to a reduction in entrepreneurs. The vertical integration of the Vaishya caste would lead to entrepreneurship, (Medhora, 1965). However, the latter argues that for a British style Industrial Revolution to have occurred in India, it would also have required a social revolution which could only have happened with state backing as had happened in Japan. But trading by the Vaishya caste signalled that the three properties of entrepreneurship, risk taking, trading for a profit and speculation all existed, (Medhora, 1965). Nevertheless, the latter suggests that although entrepreneurial aptitude had existed in India, the lack of opportunity enticed money lenders and traders to migrate to east Africa and south-east Asia. Furthermore, in the four decades of economic reform, the upper caste has become prosperous while the lower caste (scheduled castes, SC's and scheduled tribes, ST's) have not done as well, (Varshney, 2007). Moreover, in contrast to countries who at similar levels of income, India's level of entrepreneurship lags behind, (Ghani, Kerr and O'Connell, 2011). On the other hand, the number of entrepreneurs in the Other Backward Classes (Dalits) category seems to have reflected the increase in India's economic growth especially in the 1980's and the 1990's, (Judhka, 2010). Whereas in the fifteen-year period to 2005, the increase in entrepreneurship amongst the SC's and the ST's was not significant, (Iyer et al., 2013). According to the latter SC and ST entrepreneurs face prominent barriers to entry to become entrepreneurs and to benefit from economies of scale. However, OBC's seem to be making a lot of progress in the field of entrepreneurship, (Iyer et al., 2013). The difference in the ease of access to entrepreneurial opportunities between OBC's, SC's and ST's cannot be explained simply on the basis of differences in literacy rates, years of schooling or by choice of industry, (Iyer et al., 2013). Furthermore, according to the latter the underrepresentation of the SC's and the ST's in entrepreneurship and firm ownership is also common within India's 
states. This implies that this phenomenon cannot be due to specific regions of underdevelopment, (Iyer et al., 2013). Firms owned by SC's and ST's tend to be smaller than the firms owned by non-SC's. According to Iyer et al. (2013) SC's and ST's may not be able to expand the size of their firms because the caste system constrains networking which facilitates finding the right employees as well as the building of relationships with customers and with suppliers. Another factor which may be constraining the expansion of firms by SC's and ST's is the lack of infrastructure, especially that associated with the reliable supply of electricity, water, the provision of transport, indisputable title to land as well as the ability to associate a particular rate with a future payoff, (Bhide, A, 2004). The latter also suggests that small scale entrepreneurs place more emphasis on the reform of indirect taxes rather than direct taxes; and on the prevention of the theft of physical goods rather than on contract enforcement.

There were also other local private enterprise initiatives in states such as Gujarat which would have national ramifications. The Entrepreneurship Development Program (EDP) was set up in Gujarat, India in 1970 in order to promote small business enterprise, (Bhatt, 1986). This was around the same time that Town and Village Enterprises began to emerge in China. The EDP was established under the supervision of the Gujarat Industrial and Investment Corporation; and its main purpose was to select, train and guide potential entrepreneurs to identify suitable projects. However, in 1978 the Centre for Entrepreneurship Development (CDE) was established in order to oversee and administer the EDP. According to Bhatt (1986) in the fourteen years from 1970 in Gujarat 312 entrepreneurial programs with 7710 participants were conducted in 130 locations. The results suggest that $60 \%$ of the potential entrepreneurs selected and trained through the program successfully set up a business, $75 \%$ of which were profitable. The success of the CDE in promoting the EDP and small business enterprises brought Gujarat's program to national attention; and the Entrepreneurship Development Institute of India (EDI-I) was established in 1983. The aim of the EDI-I was to 'conduct research, offer consultancy and training, and assist state-level agencies in carrying out their programs', (Bhatt, 1986). In the period 1995 to 2010, the Invisible Raj, private enterprise was free to enter and set up in most parts of the economy and did not require licences to do so. However, foreign MNC's entering the Indian market lured experienced professionals from Indian enterprises which then resulted in the formation of small local microenterprises. Koster et al (2008) suggests that small scale enterprises remain a very important measure of entrepreneurship in India, while the share of small scale enterprises in the Indian economy is increasing. On the other hand, the share of registered firms seems to be static and not prone to any big changes, Koster et al (2008). According to the latter the predominance of small scale enterprises in the Indian economy; and a weak relationship between the level of GDP and the market share of registered firms suggests that entrepreneurship in the Indian economy has not yet shifted to a more formal orientation. The implication is that the level of Indian economic growth has not been sufficient enough to generate the required number of jobs to reduce necessity based entrepreneurship, (Koster $e t$ al., 2008). For the Indian government, the low number of registered firms in contrast to the number of small scale enterprises suggests that policy needs to be formulated at the state level which facilitates the development of entrepreneurial quality, (Koster et al., 2008). Increasing the level of entrepreneurial quality equates to increasing the number of registered firms in the economy in comparison to the number of small scale enterprises. Moreover, increasing the quality of entrepreneurship will have a positive impact on the level of economic development, (Wong et al., 2005). However, according to Gurtoo et al. (2009) not only did a large proportion of informal workers work on their own account but that not all work was due to economic necessity. Furthermore, that workers in the informal sector work because of need is an assumption rather than being based on evidence, (Gurtoo et al., 2009). This is in contrast to the structural approach which distinguishes between 'necessity' entrepreneurs and 'opportunity' entrepreneurs, (Aldis et al., 2006). The dichotomy between necessity based entrepreneurs and opportunity based entrepreneurs has been incorporated into the Global

Entrepreneurship Monitor (GEM) survey, (Minniti et al., 2006). GEM survey data can provide a better insight into how entrepreneurship may either be need or opportunity based. In this case, the need based drivers of entrepreneurship have been under scrutiny more than ever, especially in western nations, (Gerxhani, 2004). Interest in the nature of the informal sector in India has been spurred by the revelations that it is both large and expanding, (Chaudhari and Banerjee, 2007). Some estimates suggest that the informal sector in India is composed of $93 \%$ of the country's total workforce, (Kapoor, 2007). In contrary to conventional wisdom, it would seem that the formal sector exists on the margin while the informal sector is mainstream, (Gurtoo et al., 2009). Furthermore, according to the latter the conventional held view was that workers worked in the informal sector simply because they could not find any work or were excluded from working in the formal sector, (Gurtoo et al., 2009). In order to investigate this phenomenon, the latter conducted a nationwide survey based investigation between 2006 and 2007. The findings were in contrast to the conventional structuralist view that workers in the informal sector were largely waged workers. Moreover, the findings suggested that $49 \%$ of the workers in the informal sector worked as entrepreneurs or on their own account, (Gurtoo et al., 2009). The 2004 GEM survey also supported this view on the basis that 107 million people were keen to set up their own firms. For policy makers, the finding that informal entrepreneurs may represent the mainstream workforce in 
developing economies; and that informal entrepreneurs are in the mainstream suggests that policies supporting informal entrepreneurs need to be developed, (Gurtoo et al., 2009).

A number of explanations can be found in the literature for the nature of entrepreneurship in India. Some empirical studies suggest that Indian entrepreneurs are risk averse and so favour the service sector rather than the manufacturing or industrial sector as the service sector would require less investment and less sunk cost, (Gupta, 2008). However, other studies suggest the lack of availability of capital as well as a poor institutional support environment for entrepreneurs, (Veen, 1976). Nevertheless, other studies showed how local microenterprises evolved into industrial enterprises, thus refuting the risk averse Indian entrepreneur empirical findings, (Gupta, 2008). Another constraint on entrepreneurship in India is a lack of achievement motivation which is truer in the context of female entrepreneurs, (Shivani et al., 2006). However, according to Ghani et al. (2013) the better the local infrastructure (in rural counties as opposed to cities) then the faster the relative rate of entry of females into entrepreneurship in either manufacturing or services. As females in India have a tendency to do all household and other manual chores, better infrastructure would mean that less time would be required to complete these tasks which would mean that they would have more time to engage in entrepreneurial endeavours. At a general level Monsen et al (2012) find that living in urban areas increases the probability of an individual transitioning into self-employment.

The greater the access to local education for women, the higher the literacy rate; and the tougher the labour laws and regulations than the higher will be the level of female participation in entrepreneurship in the services sector, (Ghani et al., 2013). At a general level the quality of infrastructure as well as the quality of education are strong predictors of entrepreneurship into manufacturing (Ghani et al., 2014) and manufacturing and services in India (Ghani et al., 2012). The latter suggests that these relationships are much stronger in India than in the US. This could be because India is still at an earlier stage of development in the context of structural transformation, urbanisation and the development of the manufacturing sector, (Ghani et al., 2012). The implication is that because structural transformation, urbanisation and the development of the manufacturing sector are still at the early stages of development, central and local government economic policies will have a strong impact on the change and direction of these factors. High levels of local entrepreneurship also results in higher levels of local job creation, with entrepreneurship helping to allocate resources efficiently, enhancing competition and innovation while promoting trade, (Ghani et al., 2012). According to Ghani et al (2014) strong labour laws and access to financial institutions by households also plays a positive role in the nature of entrepreneurial activity in the manufacturing sector. Poor gender legislation protecting and ensuring women's rights equal treatment in the jobs market and the workplace means that the number of women employed in the formal sector of the economy is smaller to the numbers of women employed in the informal sector, (Torri et al., 2014). The informal sector of the economy is that which falls under the 'radar' of the government; and it is that sector of the economy which does not comply with tax collection and labour laws and regulations, (Amin et al., 2003). According to Torri et al. (2014) the lack of access to jobs in the labour market opens up other job creation opportunities in the informal sector such as community enterprises. While community enterprises such as Gram Mooligai Company Limited (GMCL), a community enterprise in the herbal sector employing untouchable females, enhances women's learning and leadership skills it does nothing to reduce the prejudices of India's caste system or improve legislation better empowering women to successfully find jobs in the formal sector of the economy, (Torri et al., 2014). Thus, according to the latter while enterprise opens new sources of income for women excluded from jobs in the formal sector, it does nothing to improve the empowerment of women. This can only be accomplished by improving India's labour laws and regulations to end gender and caste discrimination. However, Ghani et al. (2013) found that female business ownership rates were higher in southern Indian states such as Karnataka, Kerala and Tamil Nadu compared to northern Indian states such as Delhi, Bihar, Haryana and Gujarat. This may indicate that women in leadership positions is valued more in southern India than it is in northern India. However, it has been found that an increase in political reservations, positions in government bodies, resulted in an increase in female participation in entrepreneurship in manufacturing in the informal sector in which $99 \%$ of manufacturing businesses lie and which accounts for $80 \%$ of employment in India in the 1990's, (Ghani et al., 2014). Furthermore, as 70\% of India's population still live in villages, with half of this being women, enabling capacity building amongst rural women in India's villages by providing training in finance, management, marketing, production and literacy represents a powerful tool to further India's economic development, (Mehta et al., 2011). There is also a dichotomy between rich women and poor women in the context of wealth and entrepreneurial ability, (Kumbhar, 2013). Wealthy women may have access to financial resources but no entrepreneurial ability whereas poor women may have entrepreneurial ability but no access to financial resources. An easy way to resolve this dichotomy is for the government to initiate microfinance initiatives at the rural village level targeted specifically at women entrepreneurs.

Nevertheless, a rights based approach was adopted in order to ensure the development, survival and protection of women and children through the National Policy for Empowerment of Women (2001) which was adopted for implementation by the Tenth Five Year Plan (2002 -2007), (Goyal et al., 2011). Despite institutional factors, human factors are important for sustainable entrepreneurship, (Sinha, 1996). According to the latter these 
'human factors' represent the entrepreneurs style of leadership, beliefs, values, orientation, manipulative skills as well as the entrepreneur's demographics and background.

Another factor, which constrains the emergence and the development of entrepreneurship is the lack of human capital. In India human capital is on the rise, especially amongst male entrepreneurs but this is true of only a small part of the population. Despite, the constraints to entrepreneurship in India, self-reliance upon poverty is buoyant in India. For example, over fifty percent of the identifiable workforce in India is selfemployed, (Debroy and Bhandari, 2007). Furthermore, between 1993 and 2004, there was an increase of ten percent in the average income of the twenty percent of the lowest of the population, (Gupta, 2008). A similar increase occurred in the average incomes of the top twenty percent of the population. This suggests that selfenterprise is a feature of the behaviour of both the top twenty percent and the lowest twenty percent of India's population. According to some the entrepreneurial dynamism of the Indian economy is temporary because it is as been due to exogenous factors such as the return of native business leaders from abroad as well as high tech start-ups by the returned foreign born children of Indian parents, (Turner, 2007).

Some of the factors which have been constraining India's economic growth have been identified as a lack of hard and soft infrastructure which has not only constrained the development of the market in India but has also constrained the increase in the entrepreneurial participation in the economy. However, the scarcity of resources in India maybe facilitating the development of a new type of entrepreneurship which is based on a 'frugal, flexible and inclusive approach to innovation and entrepreneurship in India', (Prabhu et al., 2015). The latter suggests that the traditional mode of innovative entrepreneurship was one which was based on big corporations spending large sums of money in developing new types of goods for a relatively small number of people.

However, with a reduction in costs the goods and services would become available to a bigger proportion of the population through further innovation. Nevertheless, the nature of innovation itself is changing in the context of 'where, how and by whom' innovation is conducted, (Prabhu et al., 2015). The nature of innovation is becoming more emerging markets based, especially in the context of Brazil, China and India. Some of the features of an emerging economy include widening disparities of income between the rich and the poor and as well as a rising middle class. According to Prabhu et al (2015) a substantial amount of the innovation in these emerging economies is on a small budget, accommodates circumstances and is based on the needs of the local community. Innovators are adapting to scarcity by making best use of existing technology and resources in order to develop novel solutions to local community level problems which have not been previously addressed because of high costs, lack of knowledge and lack of commitment, (Ahlstrom, 2010). Another development in the innovation process is that the innovating agents are increasingly being characterised as social ventures, individuals, local firms and multinational firms, (Prahalad, 2012). Social ventures and individuals have the advantage of local knowledge and the tenacity and resourcefulness of the practitioners. However, they lack the ability to scale up local solutions up to a state/national level. This is due to a lack of financial resources. On the other hand, large multinational corporations have substantial financial resources in order to fulfil their corporate social responsibility obligations, although they may also be motivated by increased growth and market share, but lack local knowledge in order to provide fully comprehensive solutions. Local firms act as a conduit between social ventures and multinational corporations. According to Prabhu et al (2015) local firms have comprehensive local knowledge in order to provide the best solutions to local problems. Furthermore, local firms may have a long-term view regarding its involvement in the social venture project. The implication of this is that the project will become established and so more likely to succeed than if the firm takes a short-term view. However, even local firms may be inept in social venture projects, Prabhu et al (2015). The latter suggests that the Tata Group was short sighted in its business strategy with regards to the Tata Nano. While the Tata Nano was marketed as the world's cheapest car, Tata Group failed to realise that a large proportion of the Indian population neither had a bank account or access to loans in order to buy the Tata Nano. Government institutions and agencies have also adopted the frugal, flexible and innovative approach to social entrepreneurship. For example, the Reserve Bank of India sees financial inclusion as one of its objectives. The Aadhaar Service of the Unique ID Authority of India also seeks financial inclusion as one of its financial objectives with the additional objectives of efficiency and transparency in the context of public welfare and distribution programs, (Prabhu et al., 2015). The latter suggests that in some states, this can be also facilitated by GPS and Smart card technology. Furthermore, ICICI Bank in association with EKO, a financial service provider, and local shops has set up a financial system which allows workers from rural villages working in cities to repatriate their earnings back to their home villages. The integrated approach to social entrepreneurship taken by ICICI Bank saves costs by making use of existing technology supplied by EKO in order to deliver financial accessibility in local shops in rural villages. Prabhu et al., (2015) suggests that the cultural, societal and economical background of India presents an innovation system which is different from the traditional model which is enshrined in the innovation systems of the developed, industrial countries. These differences suggest the frugality of Indian innovators, the ad hoc approach taken to innovation in India; and the community based innovative solutions which are produced. The contemporary Indian approach to innovative social entrepreneurship whether by individuals, governments, not for profit organisations, local firms and/or multinational organisations can be associated with 
the existing knowledge of bricolage, output driven processes in a resource constrained environment, and ad hoc organisational processes and structures.

Jain and Sharma (2013) suggests that the frugal, flexible and innovative approach of Indian innovators is due to the volatility and instability of the business environment in India. This may be associated with structural shortcomings, associated with poor hard and soft infrastructure as well as with institutions which are hampered by costly and time consuming bureaucracy. Another structural deficiency of the Indian economy is that up to $40 \%$ of the population do not have bank accounts, (Prabhu et al., 2015). This lack of development of India's financial system means that Indian households are unable to borrow and to save in the conventional sense. Thus, India lacks a transparent and a necessary medium which can channel savings into loans; and so increase investment expenditure. It is also true to say that a large part of India's population does not have access to good housing, access to the electricity grid or to education and health services. The limited income of the majority of India's population, allied with no or limited access to a financial system means that a substantial proportion of Indian households are illiterate; and eat unhealthy foods which are cooked using environmentally unfriendly methods, (Dreze \& Sen, 2013). One of the problems associated with government and agency efforts to reduce the informal sector and to expand the formal sector, by improving the living conditions of households is the cost of doing so. In other words, the cost of expanding social programs, for example to connect all households in a state to the electricity grid would be formidable. A program to expand access to healthcare to all villages in a state would also face similar problems. The cost constraint on providing social services to the urban and the rural poor of India can also be associated with the development of affordable goods and services for this demographic group. While India's middle class is rising, its numbers are still dwarfed by its urban and rural poor. Nevertheless, the incomes of both demographic groups are growing although the middle-class consumption is becoming static. This means that the potential aggregate sales of goods and services to the urban and to the rural poor is huge which is why there is increased interest in the development of innovative goods and services for this demographic group. Prabhu et al (2015) suggests that entrepreneurial Indian innovators have facilitated the fulfilment of this need 'through the use of local and cheap technologies combined with clever organisational and logistical arrangements.' The typical characteristics of this approach include the use of available technology and resources, flexible thinking and a realistic approach; and the inclusion of the community with regards to product/service development and delivery.

Two example of this innovative entrepreneurial approach towards addressing the needs of India's urban and rural poor include the Solar Electric Lighting Company (SELCO) and the Mobile Diabetic Clinic, (Prabhu et al., 2015). According to the latter SELCO, a private for profit company, was set up in 1995 to provide solar powered lighting to the rural poor who would normally use kerosene lamps for lighting purposes. However, the problem was that solar panels and associated batteries were expensive and difficult to sell even to middle class Indian households, so how could they be sold to poor rural households. The owner of SELCO, Harish Hande found that the rural poor could not afford to large sums of money each day but incurring a smaller cost each day was too much a burden on household income. Hande gained the insight that the rural poor earned small amounts of money each day and spent that money the same day in order to pay for food and fuel for heating, cooking; and paying off debts, (Prabhu et al., 2015). According to the latter, Hande found that the rural poor would buy kerosene on a daily basis and spend around 25 cents on doing so. The implication of this revelation was that Hande realised that he had to be in a position to supply solar panel energy to the rural poor on a daily basis at a similar price to the kerosene that they would normally buy. In order to achieve this, Hande made use of local logistics by hiring local entrepreneurs to start up solar energy shops from which local villagers could hire solar panel charged lamps for 20 cents a day. This was a cheaper price at which Kerosene was sold. This would make solar panel charged lamps more economical to use than kerosene as well as being a healthier option as the lamps do not emit unhealthy fumes, (Prabhu et al., 2015). However, the problem is that the local entrepreneurs will not have enough capital to buy solar panels and/or lamps to start renting out solar panel charged lamps.

Nevertheless, this problem was solved when Hande guaranteed loans for the local entrepreneurs. These loans allowed the local entrepreneurs to buy the solar panels, lamps and any other equipment which they would need to start operating and renting out solar panel charged lamps to the local rural poor. It is easy to see that the solar panel solution incorporated the main features of the new emerging markets innovative entrepreneurial model. These features included the use of existing technology and innovative thinking to include the local community in the delivery of the solution to the rural poor. Another innovative social entrepreneurship initiative is the mobile diabetic clinic. In this case, local unpaid volunteers were trained in order assess whether patients had diabetes in a mobile clinic. The local volunteers may not benefit financially but they gain transferable training in the medical sector which can then be used to find other jobs in the sector. SELCO and the mobile diabetic clinic are but a small drop in improving living standards and eliminating poverty. But all such initiatives added together do contribute towards achieving these goals at least at a local level. The problem is that these local social entrepreneurship initiatives are difficult to replicate in other Indian states due to cultural, structural, economic and demographic differences between the states in India. 


\section{Discussion}

The nature of entrepreneurship in the two countries is different and this is mainly due to the differences in the formation of institutions. In 1949 China emerged as a country with a unified government under Chairman Mao and the Chinese Communist Party after decades of instability due to invasion and civil war. In this case, China started with a clean slate in terms of institutions, because the old ones had been wiped away and new ones were to form through experimentation. This path of experimentation led to the Great Leap Forward, the Cultural Revolution and the economic reforms which started in 1978. The reforms facilitated the development of adaptable and flexible institutions. On the other hand in India, British colonial rule gave way to institutional rigidity. Institution's and institutional development is important in an economy because effective institutions facilitate efficient market transactions. An institution can be regarded as a human construct which facilitates transactions between the buyers and the sellers of a good. Institution's, therefore, represents the ultimate root of the process of the allocation of labour and of capital for production by firms. Institutional development and institutional stability takes time. However, whereas market oriented reforms took a big bang approach in India, in China the market reforms were gradual and incremental over time. The implication of this is that institutions are more developed and stable in China then they are in India. Institutional development was also made easier in China because of the one party system whereas in India the multiparty democracy made it difficult for a consensus to form with regards to any economic policy. The one party advantage of China was made stronger because of the homogeneity of the Chinese population in contrast to the diversity of the Indian population. Differences in land ownership in India and China also had an impact on the development of the economy in each country. In India, land ownership was concentrated both during colonial times and after independence in 1947 when it became linked with the Congress Party. However, in China after the revolution in 1949 all land was owned by the state and agriculture was collectivised. Furthermore, in India after independence, political power became concentrated in the hands of the highly educated middle class who had been schooled in English. In conjunction with Prime Minister Nehru's focus on the promotion of scientific education, the result was that India had an abundance of low paid highly skilled labour. The concentration of power in the hands of the English educated middle class in India also meant that agricultural surpluses went straight to the landowners and not to the improvised tenant farmers and lower castes who were deprived of skills development. Nevertheless, in the case of China the concentration of political power led to the state accumulation of agricultural surpluses which were then used to build rural industry. This facilitated the development of skills by rural workers which would then be used in China's manufacturing sector after the economic reforms of 1978. At the start of economic reforms in 1978 China has an abundant supply of cheap unskilled labour which would be used by foreign multinational companies to produce and export light manufactured goods from China. In India, even if agricultural surpluses had not gone to landowners but had been used for the benefit of tenant farmers and lower castes, the rigid caste system would have prevented this happening anyway. In India the caste system dictates the occupation a person is borne into, and this can only be changed by the process of birth and rebirth. The caste system, therefore, acts as a constraint on social mobility; and may negatively impact on entrepreneurship.

In China, the roots of modern entrepreneurship lie in the emergence of Town and Village Enterprises (TVE's) in the aftermath of the decollectivisation of agriculture in the early 1980's. These TVE's had to sell a proportion of their produce to the state at a fixed price but could sell the remainder at market prices. State recognition of entrepreneurship followed in the late 1980's with the 'Tentative Stipulations on Private Enterprise' (TPSE). According to this any 'firm' with 'privately' owned assets and with more than eight employees should be registered as a private enterprise. However, in India a firm with more than ten workers becomes part of the formal sector after which arduous labour laws begin to apply. This may explain why firms in India prefer to remain small by remaining in the informal sector. As a result the firms will not benefit from economies of scale. On the other hand this does not have seemed to have happened in China. Since the start of the economic reforms in 1978, the trend in employment has been a shift away from the primary sector to the tertiary sector. Furthermore, there has been a convergence in employment between rural and urban areas in around 2010. In the reform years, and especially in the last decade the number of state owned firms as fallen in comparison to the number of 'other ownership units'. The trend has also been the same in the numbers of workers employed between the state sector and other ownership types. The data analysis also suggests that in the case of China, more private enterprises are located on the coastal province then in either the central or the western province. Private, shareholding and limited liability corporations were also seen to be more innovative then their state owned counterparts with a greater number of newer products. This is evidence for the strong link between entrepreneurship and innovation which, according to the Solow model, the long term driver of economic growth. On the other hand, in comparison in India the primary sector remains the biggest employer compared to either the secondary or the tertiary sector. Nevertheless, employment in the private sector has been rising in India since 2010, although it is still significantly less than public sector employment. However, a breakdown of the main composites of public sector employment shows that state, quasi-government and local government bodies contributes more to public sector employment than does central government. Furthermore, employment in larger firms with greater than 25 employees as been higher than employment in small firms with 
less than 25 employees, although the former has been rising since 2005 . Moreover, the number of nongovernment companies limited by share started to rise after the 1980's limited economic reforms. But this trend became more pronounced after the broader economic reforms of the early 1990s. And despite the fact that private companies are the greatest by number in the Indian economy in 2017, the numbers are far fewer than the number of private enterprises in China's coastal, central or western regions.

\section{Conclusion}

The aim of this paper has been to show that entrepreneurship in China has played an important role in its economic growth. The objective of this paper has been to show how the nature of entrepreneurship differs between China and India. The methodology used has been a case study, based on the literature and relevant data, on entrepreneurship in India and China. The Solow model is the standard mainstream economic growth model in economic theory. The premise of this model is that the higher the level of savings in an economy then the higher will be the level of investment in fixed capital. However, over time more and more investment will be for replacement machinery, to replace earlier machinery worn out through use. This is known as depreciation. As a result of the need to replace original machinery due to wear and tear means that additional investment will lead to less economic growth over time. This can only be reversed if the level of savings increases but this cannot happen indefinitely. Therefore, the only other way in which the economy can grow is through technological innovation which is assumed to be freely available to all firms in the economy. However, the model says nothing about either how this technological progress occurs or how it encounters the economy and facilitates economic growth. This paper has shown through the evaluation of the Chinese economy that the process of technological progress occurs through a process of innovation and entrepreneurship which facilitates knowledge spillovers from centres of research to commercialisation. Entrepreneurship is more developed in China than in India; and therefore it has played a bigger role in China's economic growth than it has done in India's economic growth. The predominance of small scale enterprises in the Indian economy; and a weak relationship between the level of GDP and the market share of registered firms suggests that the level of entrepreneurship in India is not yet as widely prevalent as it is in China. This view is supported by other research. For example, new business density in India was 0.12 while in Hong Kong SAR, China it was 31.3. The new business density is measured as the ratio of the number of newly registered corporations per 1000 working age people between the ages of 15 and 64, (World Bank, 2016). However, there is no measure for the measure of new business density in mainland China. In this case, the new business density for Hong Kong SAR can act as a proxy for the measure in mainland China. Both have similar culture and the mainland has benefited hugely from investment originating from Hong Kong SAR. Furthermore, according to Zoltan et al (2016), in terms of the level of entrepreneurship, China is at $60^{\text {th }}$ position in the world with an entrepreneurial measure of 34.9; with India at position $98^{\text {th }}$ in the world with an entrepreneurial measure of 24.9. This indicates that entrepreneurship is stronger in China than in India. Entrepreneurship has been stimulated in China by the incrementally evolving economic reforms which started in 1978. This is a self-reinforcing process which drives China's economic growth. However, entrepreneurship in India remains constrained by institutional factors. Due to this the social entrepreneurship is more prevalent in India than in China. The frugal, flexible and innovative approach of Indian innovators is due to the volatility and the instability of the business environment in India. This may be associated with structural shortcomings associated with poor hard and soft infrastructure; and inept institutions characterised by time consuming bureaucracy and corruption. In these circumstances, Indian entrepreneurs are risk averse in contrast to their risk seeking Chinese counterparts. Furthermore, in India there is an overlap between Chinese cultural values and general entrepreneurial values such as perseverance, diligence and resourcefulness. In general, informal entrepreneurs may represent the mainstream work force in developing economies; and this may be due to the lack of formal job openings. This indicates the importance of suitable policy development by the governments of developing economies, like India, to support informal entrepreneurs.

\section{$\underline{\text { References }}$}

Acs, A.J., \& Szerb, L. (2010), The Global Entrepreneurship and Development Index (GEDI). In Paper presented at 'Opening up Innovation: Strategy, Organisation and Technology”. London: Imperial College.

Ahlstrom, D., and Bruton, G.D. 2002. An institutional perspective on the role of culture in shaping strategic actions by technology-focused entrepreneurial firms in China. Entrepreneurship Theory and Practice, 26(4).

Ahlstrom, D. (2010), Innovation and growth; how business contributes to society. Academy of Management Perspectives, 24(3); $1-23$

Aidis, R., Welter, F., Smallbone, D., and Isakova, N. (2006), Female entrepreneurship in transition economies: the case of Lithuania and Ukraine, Feminist Economics, Vol 13, No 2, pp 157-183. 
Alon, I., and Lerner, M. (2008), International Entrepreneurship in China: Lessons from Global Entrepreneurship Monitor. Paper presented at the Next Globalisation Conference on Transnational Entrepreneurship, $30^{\text {th }}$ April 2008, http://citeseerx.ist.psu.edu/viewdoc/download?doi=10.1.1.475.8637\&rep=rep1\&type=pdf

Amin, S., Rai, A., and Topa, G. (2003), Does microcredit reach the poor and vulnerable? Evidence from Northern Bangladesh, Journal of Development Economics, 70, 59-82.

Arnold, R. (2008), Economics, Thomson Learning Inc

Appleton, S., Knight, J., Song, L., and Xia, Q. (2004), Contrasting Paradigms: Segmentation and Competitiveness in the Formation of the Chinese Labour Market, Journal of Chinese Economic and Business Studies, Vol. 2, No. 3.

Audretsch, D. (2007), Entrepreneurship Capital and Economic Growth, Oxford Review of Economic Policy, Vol. 23, No. 1, pp.63-78.

Baporikar, N. (2015), Role of Entrepreneurship in the Networked Indian Economy, in Technological Solutions for Sustainable Business Practice in Asia, Pablos, P. (eds), IGT Global, USA.

Batjargal, B., and Liu, M., (2004), Entrepreneurs Access to Private Equity in China: The Role of Social Capital, Organisation Science, Vol.15, No. 2.

Baumol, W. (1990), Entrepreneurship: Productive, Unproductive and Destructive, The Journal of Political Economy, Vol.98, No. 5.

Bergmann, H., and Sternberg, R. (2007), The changing face of entrepreneurship in Germany, Small Business Economics, 28(2-3), 205-221.

Bhatt, V. (1986), Entrepreneurship and Development: India's Experience, Finance and Development, $23,1$.

Bhide, A. (2004), What role for entrepreneurship in India, Memo, Graduate School of Business, Columbia University, https://www0.gsb.columbia.edu/mygsb/faculty/research/pubfiles/2187/Bhideentre.pdf

Block, J., and Sandner, P. (2009) Necessity and opportunity entrepreneurs and their duration in selfemployment: Evidence from German micro data. Journal of Industry, Competition and Trade, 9(2), 117-137.

Brimmer, A. (1955), The Setting of Entrepreneurship in India, The Quarterly Journal of Economics, Vol.69, No. 4

Bruton, G., Ahlstrom, D., and Obloj, K. (2008), Entrepreneurship in Emerging Economies: Where Are We Today and Where Should the Research Go in the Future, Entrepreneurship Theory and Practice, 32, 1.

Carree, M., van Stel, A., Thurik, A.R. and Wennekers, A.R.M. (2007), The relationship between economic development and business ownership revisited. Rotterdam: Tinbergen Institute.

Cooke, F. (2009), The Enactment of Three New Labour Laws in China: Unintended Consequences and the emergence of 'new' actors in Employment Relations, Keynote Speech, Conference of the Regulating for Decent Work Network, ILO, Geneva, Switzerland, 8-10 July 2009.

Chaudhari, S., and Banerjee, D. (2007), Economic liberalization, capital mobility and informal wage in a small open economy: a theoretical analysis, Economic Modelling, Vol 24, pp 924-940.

Debroy, B., and Bhandari, L. (2007), Exclusive Growth - Inclusive Inequality, Working Paper, Centre for Policy Research, New Delhi.

De Marco, A. (2000), Uncertainty and New Venture Investments: Some Empirical Evidence from Young Italian Firms, International Journal of Entrepreneurship, Vol. 4.

Deng, S., Wang, X., and Alon, I. (2011), Framework for female entrepreneurship in China, International Journal of Business and Emerging Markets, 2(1):3-20.

Djankov, S., Qian, Y., Roland, G., and Zhuravskaya, E. (2006), Entrepreneurship in China and Russia Compared, Journal of the European Economic Association, Vol.4, No 2/3.

Dreze, J., and Sen, A. 2013. An uncertain glory: India and its contradictions. Princeton: Princeton University Press.

Fan, Y. 1996. Global perspectives: Chinese peasant entrepreneurs: An examination of township and village enterprises in rural China. Journal of Small Business Management, 34(4). 
Fields, G., and Yang, S. (2013), A theoretical Model of the Chinese Labour Market, Discussion Paper Series, Forschungsinstut Zur Zukunft de Arbeit, No. 7278.

Gennaioli, N., La Porta, R., Lopez-de-Silanes, F., \& Shleifer, A. (2013). Human Capital and Regional Development. Quarterly Journal of Economics, 128, 105-164.

Gerxhani, K. (2004), 'The informal sector in developed and less developed countries: a literature survey', Public Choice, Vol 120, No 2, pp 267-300.

Ghani, E., Kerr, W., and O’Connell, S. (2011), Promoting Entrepreneurship Growth and Job Creation, in Ghani, E. (Ed), Reshaping Tomorrow: Is South Asia Ready for the Big Leap, New Delhi, Oxford University Press.

Ghani, E., Kerr, W., and O'Connell, S. (2011), Local industrial structures and female entrepreneurship in India, Journal of Economic Geography, pp.1-36.

Ghani, E., Kerr, W., and O'Connell, S. (2012), What Makes Cities More Competitive? Spatial Determinants of Entrepreneurship in India, Policy Research Working Paper 6198, The World Bank.

Ghani, E., Kerr, W., and O’Connell, S. (2014), Spatial Determinants of Entrepreneurship in India, Regional Studies, Vol. 48, Issue 6.

Goyal, M., and Parkash, J. (2011), Women Entrepreneurship in India - Problems and Prospects, International Journal of Multidisciplinary Research, Vol 1, Issue 5.

Gupta, V. (2008), An Inquiry into the Characteristics of Entrepreneurship in India, Journal of International Business Research, Vol.7, 1.

Gurtoo, A., and Williams, C. (2009), Entrepreneurship and the informal sector: Some lessons from India, Entrepreneurship in India, Vol. 10, No. 1.

Hafer, R., and Jones, G. (2015), Are entrepreneurship and Cognitive skills related? Some international evidence, Small Business Econ, 44, 283-298.

Hartog, J., Van Praag, M., \& Van Der Sluis, J. (2010). If you are so smart, why aren't you an entrepreneur? Returns to cognitive and social ability; Entrepreneurs versus employees, Journal of Economics and Management Strategy, 19, 947-989.

Holcombe, R.G. (1998). Entrepreneurship and economic growth. The Quarterly Journal of Austrian Economics, $1,45-62$.

Holt, D. (1997), A Comparative Study of values among Chinese and US entrepreneurs: pragmatic convergence between Contrasting Cultures, Journal of Business Venturing, 12, No.6.

Huang, Y. (2008), Capitalism with Chinese Characteristics: Entrepreneurship and the State, Cambridge University Press, New York.

Iyer, L., Khanna, T, T., and Varshney, A. (2013), Caste and Entrepreneurship in India, Vol.XLVIII, No.6, Economic and Political Weekly.

Jain, M. (2013), Role of Entrepreneurship in Indian Economy, Journal of Social Welfare and Management, Vol.5, No. 3.

Jain, S., and Sharma, D. (2013), Institutional logic migration and industry evolution in emerging economies: The case of technology in India, Strategic Entrepreneurship Journal, 7(3); 252-271.

Kapoor, A. (2007), 'The SEWA way: shaping another future for informal labour', Futures, Vol. 39, pp. 554-568.

Koster, S., and Rai, S. (2005), Entrepreneurship and Economic Development in a Developing Country: A Case Study of India, The Journal of Entrepreneurship, 17, 2: 117-137.

Kirby, D., and Ying, F. (1995), Chinese Cultural Values and Entrepreneurship: A Preliminary Consideration, Journal of Enterprising Culture, 3, No. 3.

Krug, B., and Hendrischke, H. (2002), Entrepreneurship in China: Institutions, Organisational Identity and Survival: Empirical Results from Two Provinces, ERIM Report Series Research in Management, ERS-2002-14ORG.

Kshetri, N. (2007), Institutional Changes Affecting Entrepreneurship in China, Journal of Developmental Entrepreneurship, 12(4), 415-432. 
Kumbhar, V. (2013), Some Critical Issues of Women Entrepreneurship in Rural India, European Academic Research, Vol. 1, Issue 2.

Longbao, W. (2009), Regional Economic Development and Entrepreneurship in China, Paper Prepared for the Conference, "US-China Business Cooperation in the $21^{\text {st }}$ Century: Opportunities and Challenges for Enterprises,” Indiana University, Indianapolis and Bloomington, Indiana, April 15-17, 2009. http://www.indiana.edu/ rccpb/uschinacooperation/papers/P7\%20Wei\%20Longbao.pdf

Li, H., Li, L., Wu, B., and Xiong, Y. (2012), The End of Cheap Chinese Labour, The Journal of Economic Perspectives, Vol. 26, No.4

Liao, D., and Sohmen, P. (2001), The Development of Modern Entrepreneurship in China, Stanford Journal of East Asian Affairs, Volume 1.

Liu, Y. (2002), Development of Private Entrepreneurship in China: Process, problems and countermeasures, Chinese Academy of Social Sciences.

Lu, J., and Tao, Z. (2007), Determinants of Entrepreneurial Activities in China, MPRA Paper No. 5675.

Lucas, R. (1993), 'Making a Miracle', Econometrica, 61,251-72.

Lynn, R., \& Meisenberg, G. (2010), National IQs calculated and validated for 108 nations. Intelligence, 38, 353360.

Medhora, P. (1965), Entrepreneurship in India, Political Science Quarterly, Vol. 80, No. 4

Meisenberg, G. (2012). National IQ and economic outcomes. Personality and Individual Differences, 53, 103 107.

Meng, X. (2012), Labor Market Outcomes and Reforms in China, The Journal of Economic Perspectives, Vol. 26, No.4.

Mehta, A., and Mehta, M. (2011), Rural Women Entrepreneurship in India: - opportunities and challenges, International Conference on Humanities, Geography and Economics, Pattaya, Dec 2011.

Millman, C., Matlay, H., Liu, F. (2008), Entrepreneurship education in China: a case study approach, Journal of Small Business and Enterprise Development, Vol. 15 Iss 4 pp. 802 - 815

Minniti, M., Bygrave, W., and Autio, E. (2006), Global Entrepreneurship Monitor: 2005 Executive Report, London Business School, London.

Monsen, E., Mahagaonhar, P., and Dienes, C. (2012), Entrepreneurship in India: the question of occupational transition, Small Business Economics, Vol.39, No. 2.

Naude, W., and Rossouw, S. (2010), Early International Entrepreneurship in China: Extent and Determinants, J Int Entrep, 88.

Parthasarathy, B., and Aoyama, Y. (2006), From Software Services to R\&D Services: Local entrepreneurship in the Software Industry in Bangalore, India, Environment and Planning A, Vol. 38, pp. 1269 - 1285.

Phan, P., Zhou, J., and Abrahamson, E. (2010), Creativity, Innovation and Entrepreneurship in China, management and Organisation Review, 6:2, pp.175-194.

Prahalad, C.K (2012), Bottom of the pyramid as a source of breakthrough innovations, Journal of Product Innovation Management, 29(1):6-12.

Ramesh, S. (2012), 'China’s Transition to a Knowledge Economy,' Volume 2, No.2, Journal of the Knowledge Economy.

Ramesh, S. (2012), Continental Shift: China and the Global Economic Crisis in Rising China in the Changing World Economy, Wang, L. (Ed) Routledge/Taylor and Francis Group, April 2012.

Romer, P. (1986), 'Increasing Returns and Long-run Growth’, Journal of Political Economy, 94, $1002-37$.

Shivani, S., Mukherjee, S.K., and Saran, P. 92006), Socio-Cultural Influences on Indian Entrepreneurs: The needs for Appropriate Structural Intervention, Journal of Asian Economics, 17, 1.

Sinha, T. (1996), Human factors in Entrepreneurship Effectiveness, The Journal of Entrepreneurship, 5, 1.

Smith, A. (1776), 'An Inquiry into the Nature and Causes of The Wealth of Nations: Representative Selections', Mazlish, B. (Eds), 1961, Bobbs-Merrill Company Inc, New York. 
Solow, R. (1956), 'A Contribution to the Theory of Economic Growth', Quarterly Journal of Economics, 70(1), 65-94.

Solow, R. (1957), 'Technical Change and the Aggregate Production Function', Review of Economics and Statistics, 39,312-20.

Swetha, T., and Rao, K. (2013), Entrepreneurship in India, International Journal of Social Science and Interdisciplinary Research, Vol. 2, No. 7

Tan, J. 2005. Venturing in turbulent water: A historical perspective of economic reform and entrepreneurial transformation, Journal of Business Venturing, 20(5).

Torri, M., and Martinez, A. (2014), Women's empowerment and micro-entrepreneurship in India: Constructing a new development paradigm?, Progress in Development Studies, 14, 1, pp.31-48.

Tripathi, D. (1981), Occupational mobility and industrial entrepreneurship: A historical analysis, The Developing Economies, 19, 52-68.

Tsang, E.W.K. (1994), Threats and opportunities faced by private businesses in China. Journal of Business Venturing, 9(6).

Turner, P. (2007), Entrepreneurship: Riding Growth in India and China, http://knowledge.insead.edu/economics-politics/entrepreneurship-riding-growth-in-india-and-china-2084.

Van Praag, M., van Witteloostuijn, A., \& van der Sluis, J. (2013). The higher returns to formal education for entrepreneurs versus employees, Small Business Economics, 40, 375-396.

Varshney, A. (2007), India's Democratic Challenge, Foreign Affairs, March-April.

Veen, J.H. (1976), Commercial Orientation of Industrial Entrepreneurs in India, Economic and Political Weekly, 11, 35.

Wang, S. (2012), Credit Constraints, Job Mobility, and Entrepreneurship: Evidence from Property Reform in China, The Review of Economics and Statistics, 94, 2, pp. 532-551.

Wong, P.K., Ho, Y.P., and Autio, E. (2005), Entrepreneurship, Innovation and Economic Growth: Evidence from GEM data, Small Business Economics, 24, 3:335-50.

World Bank (2016), Doing Business - Entrepreneurship, http://www.doingbusiness.org/data/exploretopics/entrepreneurship

Wing, C.C.K., and Yiu, M.F.K. 2000. Small business and liquidity constraints in financing business investment Evidence from Shanghai's manufacturing sector, Journal of Business Venturing, 15.

Xiaoyi, Liao (2015), Building a Loho Homeland with Traditional Wisdom, Alitto, G (2015), (Eds), Contemporary Confucianism in Thought and Action, Springer.

Yang, J., and Li, J. (2008). The development of entrepreneurship in China, Asia pacific J.Manage, 25.

Yiu, D., and Lau, C.M. (2008), Corporate entrepreneurship as resource capital configuration in emerging market firms, Entrepreneurship Theory and Practice, 32, 37-58.

Yu, J., Stough, R., and Nijkamp, P. (2009), Governing Technological Entrepreneurship in China and the West, Public Administration Review, Vol. 69, Comparative Chinese/American Public Administration (Dec., 2009, pp. S95-S100.

Zapalska, A.M., and Edwards, W. 2001. Chinese entrepreneurship in a cultural and economic perspective. Journal of Small Business Management, 39, 3.

Zoltan, A., Szerb, L., and Autio, E. (2016), Global Entrepreneurship and Development Index 2016, Springer Zhou, Y., and Qin, Y. (2012), Empirical Analysis on Income Inequality of Chinese Residents, Springer. 